\title{
Finite Element Modeling of Partially Composite Castellated Beams
}

\author{
R. E. S. Ismail \\ Department of Civil \\ Engineering, Beirut Arab \\ University-Tripoli-Branch, \\ Lebanon (On Secondment from \\ Alexandria University, \\ Alexandria, Egypt)
}

\author{
A.S. Fahmy \\ Department of Civil \\ Engineering, Alexandria \\ University, Alexandria, Egypt
}

\author{
N. M. Tawfik \\ Department of Civil \\ Engineering, Alexandria \\ University, Alexandria, Egypt
}

\begin{abstract}
The aim of this paper is to present nonlinear three dimensional finite element models for both simple and continuous partially composite castellated beams under vertical loads using ABAQUS software. The initial geometric imperfection and material nonlinearities were carefully considered in the analysis. At first, Eigenvalue analysis is carried out to obtain the elastic buckling load and the corresponding buckling mode. In order to trace the entire load-deflection curve, the first buckling mode is factored and inserted into the inelastic geometrical nonlinear analysis of the beam as initial imperfection. Different modeling techniques available in ABAQUS are used for modeling of the shear connectors. The reliability of the models is demonstrated by comparisons with experiments and with alternative numerical and analytical analyses for simple and continuous composite beams. In addition, a parametric study is carried out to investigate the effect of change in cross-section geometries, beam length, alignment of stiffeners, concrete strength, steel strength and concrete slab thickness on the buckling and the overall structural behavior of continuous partially composite castellated beams under vertical loads. A total of 96 continuous partially composite castellated beams are studied. Based on the findings of the finite element results, a number of recommendations on the methods of modeling and on the design of continuous steel-concrete composite castellated beams are suggested.
\end{abstract}

\section{Keywords}

Castellated beams, partially composite beams, Distortional buckling, Finite element.

\section{INTRODUCTION}

Castellated beams are fabricated through two phases, first one cutting a rolled beam's web in a zigzag pattern along its center line and second one rejoining the two halves by welding, as shown in Figure 1, so the overall beam depth is increased by $50 \%$ and an enhanced structural performance against bending is achieved. The application of these structural members may lead to substantial economies of material and other advantages including greater bending rigidity, larger section modulus, optimum self-weight-depth ratio, economic construction, ease of services through the web openings.

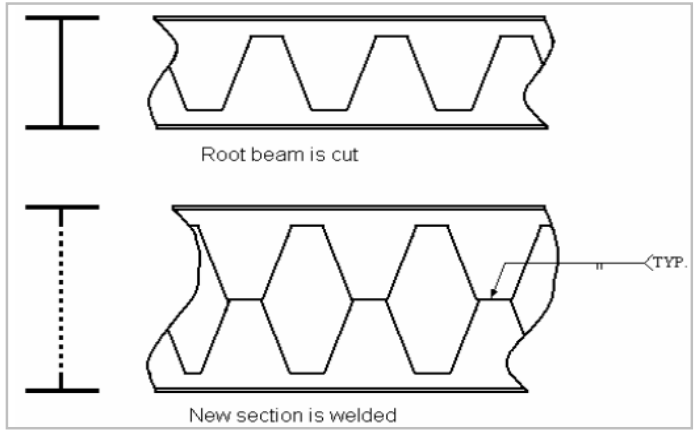

Fig 1: Fabrication process of a castellated beam

However, the castellation of beams results in distinctive failure modes, detailed by Nethercot and Kerdal (1982). They concluded that under given applied transverse or coupling forces, failure is likely to occur by one of the following modes: vierendeel or shear mechanism, flexural mechanism, lateral torsional buckling of the beam, rupture of welded joints, shear buckling of web posts, and compression buckling of web posts. Comparing to non-composite castellated beams, a few work has been done on composite castellated beams. Composite castellated beams can be employed in long span floors where the services can pass through the web-openings leading to minimum floor heights. The composite action develops a force in the concrete slab which in turns increases the effective depth of the beam and raises the neutral axis closer to the top flange, by this way, an increase in the stiffness and strength can be achieved. However, similar to the noncomposite castellated beams, the local bending and shear strength of the web posts and upper and lower tees can limit the load carrying capacity of a composite beam. Larnach and Park (1964) have conducted tests on six different castellated composite T-beams under heavy shear loading to study the composite action between castellated beams and a concrete slab. The beams were fabricated from universal sections and spiral shear connectors were used to attach the top concrete flange to the steel beam. The beams were loaded by several point loads. The failure occurred by buckling of interior web panels and cracking of the under face of the concrete flange. Also it was found that at a section with a solid web, the neutral axis position was lower than the apparent position of the neutral axis at a section with a web opening. Tests on two composite hybrid castellated beams subjected to uniformly distributed load were performed by Giriyappa and Baldwin (1966), where buckling occurred only 
after general yielding of the tension flange and after the posts in the region of maximum shear developed full plastic shear yielding. Hartono and Chiew (1996) conducted experimental and numerical studies on six composite half castellated beams, one half of a castellated beam with a horizontal flange plate welded to the top of the web posts and shear studs attached to the plate. The beams were simply supported and they were tested to failure under the action of two concentrated loads. At first, development of longitudinal cracks along the beam's span was observed, followed by transverse cracking of the slab near the supports. The ultimate failure of the beams occurred when the steel web-post, nearest to the support, buckled. A comparison between the nonlinear behavior and the corresponding failure load and mode was then done with those obtained from numerical modeling using finite element analysis. Three-dimensional solid elements were used to model the specimens, and good agreement was observed between the experimental and numerical results. Megharief (1997) tested up five castellated composite beams to failure at the Structural Engineering Laboratory of McGill University, where he observed the behavior of simply supported composite castellated beams under the sagging moment, and then modeled their behavior numerically with use of the finite element (FE) technique. The solution of highly nonlinear problems, such as the behavior of steel concrete composite beams with web openings, was enhanced significantly by this (FE) technique. Gizejowski and Salah (2011) investigated the behavior of statically indeterminate single and multi-span composite beams (plain-webbed and castellated) using the FE simulation technique. Regarding to the stability behavior of slender section steel concrete composite beams with web openings, experimental investigation and numerical finite element modeling were established by Salah and Gizejowski (2008a, 2008b) where a full composite action was assumed. They tested twelve composite beams under hogging bending, and simulated numerically their experimentally observed behavior with use of ABAQUS software. They also conducted parametrical studies on a number of continuous full composite castellated beams with same web-opening area but with different shapes, like rectangular, hexagonal and circular. Based on their experimental and numerical studies, they reported that castellated composite beams are more sensitive to different modes of distortional buckling than their plain webbed counterparts. Little investigations on the strength of continuous castellated composite beam systems were done compared to plain composite beams, where different instability effects start to play an important role, especially in the hogging moment zone, Gizejowski and Salah (2007), where the laterally unrestrained bottom flange is sensitive to a local and/or a restrained distortional buckling phenomenon. Distortional buckling (DB) is a buckling mode in which lateral deflection and twists occurred with changes in the cross sectional shape, this is due to web distortion as in most I sections, flanges are comparatively stocky and any flange distortions are small. Web distortion allows the flanges to deflect laterally with different angles of twist, reduces the resistance of the member and consequently reduces the resistance to buckling. Therefore the ultimate resistance of a continuous composite castellated beam is governed by distortional lateral buckling, local buckling, or an interactive mode of the two which is sharply different from the torsional buckling mode in a bare steel beam. In this paper, efficient nonlinear 3D Finite Element Model using ABAQUS software is developed for the analysis of steel-concrete composite castellated beams with partial shear connection. The accuracy and reliability of the model is demonstrated by analyzing simple and continuous composite beams. A comparison between the numerical results with the corresponding experimental data is made and good agreements are found. In addition, a parametric study is carried out to investigate the effect of change in cross-section geometries, beam length, alignment of stiffeners, concrete strength, steel strength, and concrete slab thickness on the buckling and the overall structural behavior of continuous partially composite castellated beams under vertical loads.

\section{FINITE ELEMENT MODELING}

In this study, the finite element software ABAQUS (2008) is used for the analysis of partially composite castellated beam. Doubly curved shell elements 4-node and 3-node with reduced integration S4R and S3R, were used to model the flanges, web and the concrete slab, as shown in Figure 2. The steel reinforcing bars in the concrete slabs were modeled in the present study as smeared layers (rebar layers) with a constant thickness in shell elements. The thickness of each steel rebar layer was calculated as the area of a reinforcing bar divided by the spacing of reinforcing bars. Four layers were used to represent the top and bottom longitudinal and transverse reinforcing bars in the concrete slab. The material property of reinforcing bars was defined in the material section.

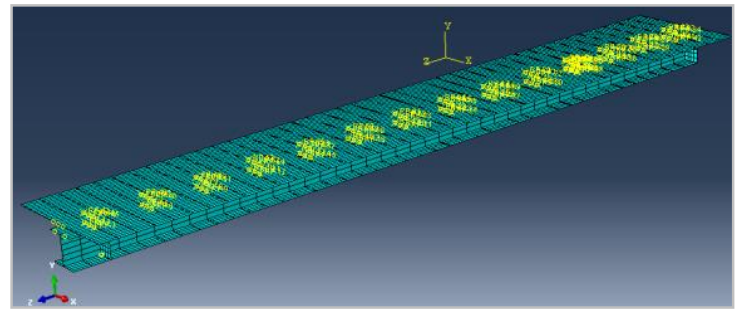

Fig 2: Typical finite element mesh for composite beams

As for steel material, the stress-strain relationship is linear elastic up to yielding, perfectly plastic between the elastic

limit $\left({ }^{\varepsilon} y\right)$ and the beginning of strain hardening and follows the constitutive law used by Gattesco (1999) for the strain hardening branch:

$$
\sigma_{s}=\boldsymbol{f}_{s y}+\boldsymbol{E}_{s h} \varepsilon_{s}-\varepsilon_{s h} \cdot\left(1-\boldsymbol{E}_{s h} \cdot \frac{\varepsilon_{s}-\varepsilon_{s h}}{4 \boldsymbol{f}_{s u}-\boldsymbol{f}_{s y}}\right)
$$

Where $f_{s y}$ and $f_{s u}$ are the yield and ultimate tensile stresses of the steel component, respectively; $\boldsymbol{E}_{s h}$ and $\varepsilon_{s h}$ are the strain-hardening modulus and the strain at strain hardening of the steel component, respectively, as shown in Figure 3. 


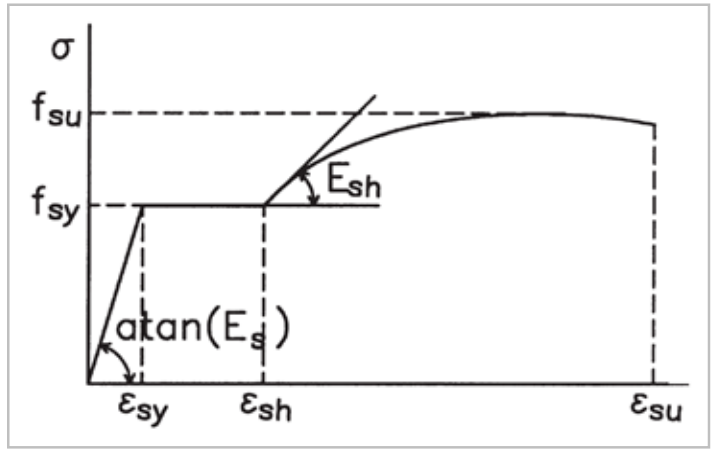

Fig 3: Steel and reinforcement stress strain curve, Gattesco (1999)

As for concrete material, the so-called SC model (smeared crack model) available in ABAQUS is used. The uniaxial stress-strain relationship for concrete proposed by Carreira and Chu (1985), as shown in Figure 4, is adopted in the present study. The compressive strength is evaluated by:

$$
\boldsymbol{f}_{\boldsymbol{c}}=\frac{\boldsymbol{f}_{\boldsymbol{c}}^{\prime} \gamma_{c}\left(\frac{\varepsilon_{\boldsymbol{c}}}{\varepsilon_{c}^{\prime}}\right)}{\gamma_{c}-1+\left(\frac{\varepsilon_{\boldsymbol{c}}}{\varepsilon_{c}^{\prime}}\right)^{\gamma_{c}}}
$$

Where $f_{c}=$ compressive stress in concrete, $\varepsilon_{c} \varepsilon_{=\text {compressive }}$ strain in concrete, $f_{c}^{\prime}=$ cylinder compressive strength of concrete, ${ }^{\varepsilon^{\prime}} c=$ strain corresponding to $f^{\prime}{ }_{c}$ and $\gamma_{c}$ is defined by:

$$
\gamma_{c}=\left|\frac{\boldsymbol{f}_{c}^{\prime}}{32.4}\right|^{3}+1.55
$$

The concrete slab compressive strength is taken as the actual cylinder strength test value. The concrete tensile strength and the Poisson's ratio are assumed as $1 / 10$ of its compressive strength and 0.2, respectively. The concrete elastic modulus is evaluated according to Eurocode 4 (1992),

$$
E_{c}=9500 f_{c}+8^{1 / 3}\left(\frac{\gamma_{c}}{24}\right)^{1 / 2}
$$

Where $\gamma_{c}$ is equal to $24 \mathrm{kN} / \mathrm{m}^{3}$.

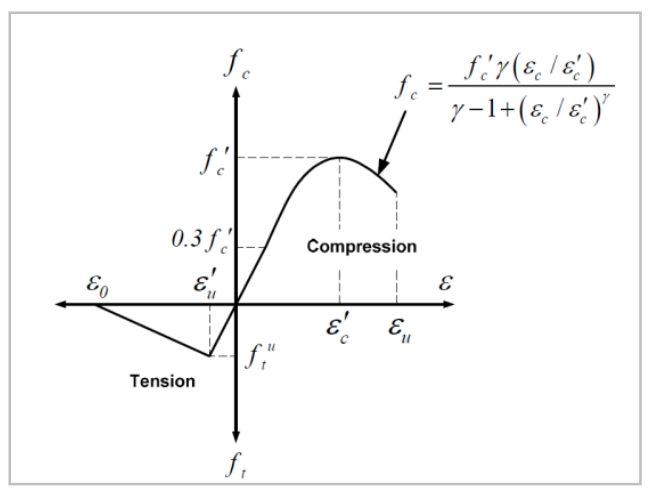

Fig 4: Concrete stress strain curve, Carreira and Chu (1985)

As for concrete in tension, the post failure behavior for direct straining across cracks is modeled with tension stiffening, which allows you to define the strain-softening behavior for cracked concrete. The stress strain relationship shown in Figure 5 assumes that the tensile stress increases linearly with an increase in tensile strain up to concrete cracking. The value in tension stiffening is an important parameter that affects the solution of a nonlinear analysis of reinforced concrete. For heavily reinforced concrete slabs, the total strain at which the tensile stress is zero is usually taken as 10 times the strain at failure in the tension stiffening model. However, it has been found that this value was not adequate for concrete slabs in composite beams (Baskar et. al. 2002, Liang et al. 2005).

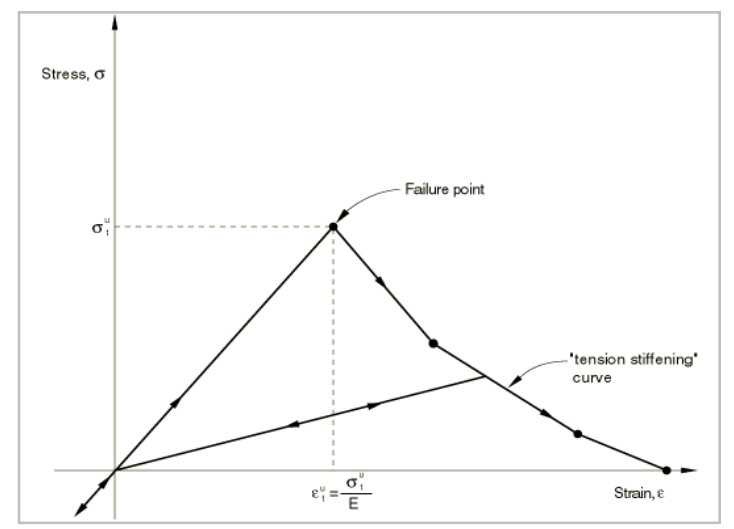

Fig 5: "Tension stiffening" model Hibbitt and Sorensen, (2008)

For modeling of shear connectors, ABAQUS provides several ways for modeling of shear connection between the concrete slab and the steel top flange, among these ways the connector element and the beam element. Both ways were used and it was found that the connector element was better than the beam element because the connector can simulate the nonlinear load-slip curve of the connector. Connector elements called CARTESIAN connectors were used, which provide a connection between two nodes where the response in three local connection directions is specified. Connector elements were used to simulate partial shear connection, while full connection can be modeled using multipoint constraints (MPC). Linear and Nonlinear elastic connector elements plus Contact interactions were used for modeling of partial shear connection. The load-slip curve for the studs is used by defining a table of force values and relative displacements (slip) as input data for the nonlinear connectors. The load-slip 
relationship of the connector is represented by the equation (Figure 6):

$Q=Q_{u} \cdot 1-e^{-\beta \cdot s^{\alpha}}$

Where $Q_{u}$ is the ultimate load of the connector, $\alpha$ and $\beta$ are coefficients to be determined from the experimental results. Also ABAQUS offers a surface interaction relationship called "no separation", which is used to model this type of hard contact behavior between two surfaces with no penetration or separation.

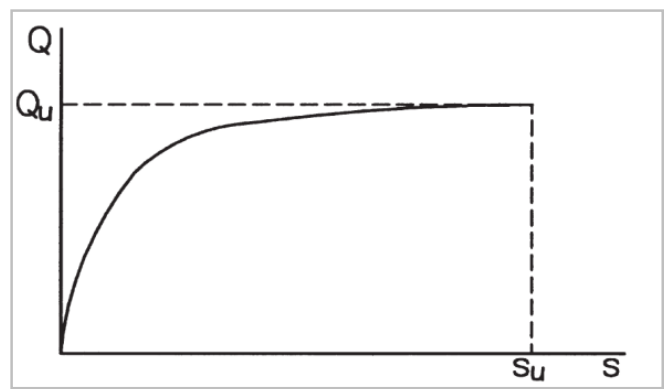

Fig 6: Load-Slip curve of the shear studs, Gattesco (1999)

Only half of the beams tests were modeled due to symmetry as shown Figure 2. Boundary conditions were prescribed to prevent the rigid body motion of the beams during the buckling and nonlinear analysis. The load was applied incrementally as distributed static load over the beam. At first, Eigenvalue analysis is carried out to obtain the elastic buckling load and the corresponding buckling mode. The first buckling mode is factored by a magnitude of Lu/1000 where $\mathrm{Lu}$ is the length between points of effective bracing. In order to trace the entire load-deflection curve, the factored first buckling mode is inserted as initial geometry into the inelastic geometrical nonlinear analysis of the beam.

\section{VERIFICATION OF FINITE ELEMENT MODELING}

Two comparisons between the numerical results obtained by the computer program ABAQUS and the experimental results reported by Chapman and Balakrishnan (1964) for simple composite beam (beam E1) and that reported by Ansourian (1981) for continuous composite beam (beam CTB 4) are made. The properties for beam E1, shown in Figure 7, are listed in Tables 1 and 2, while those for beam CTB 4, shown in Figure 8, are listed in Tables 3 and 4.

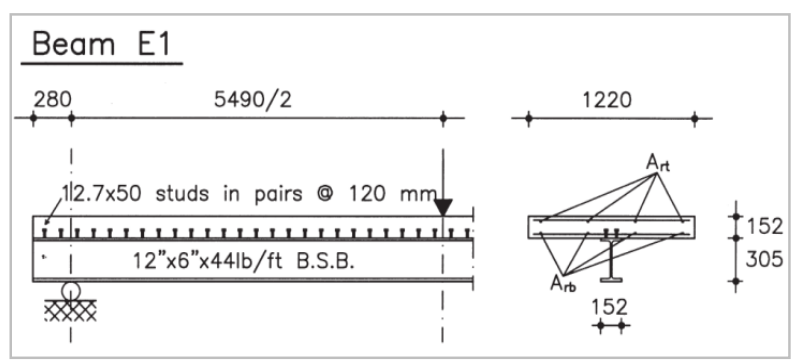

Fig 7: Simply supported test beam E1 layout

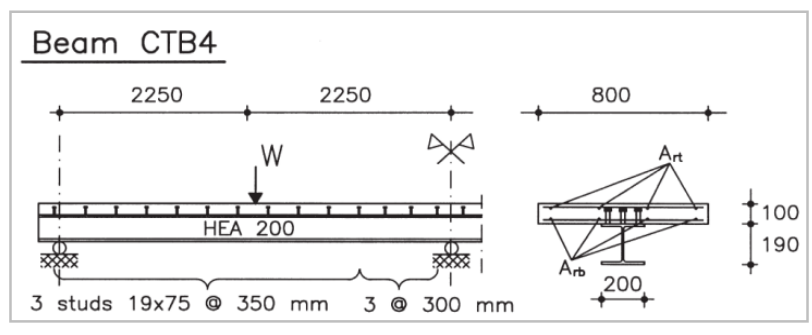

Fig 8: Continuous test beam CTB4 layout

Table 1. Geometrical characteristics of simply supported test beam E1

\begin{tabular}{|c|c|c|}
\hline $\begin{array}{c}\text { Beam } \\
\text { identification }\end{array}$ & & E1 \\
\hline $\begin{array}{l}\text { Span Length } \\
(\mathrm{mm})\end{array}$ & & 5490 \\
\hline Loading type & & $\begin{array}{c}\text { Midspan } \\
\text { point load }\end{array}$ \\
\hline \multirow[t]{2}{*}{ Concrete slab } & $\begin{array}{c}\text { Thickness } \\
(\mathrm{mm})\end{array}$ & 152.4 \\
\hline & Width (mm) & 1220 \\
\hline \multirow[t]{2}{*}{ Steel beam } & Section & $\begin{array}{c}12 " \text { x } 6 " \text { x } \\
441 \mathrm{~b} / \mathrm{ft} \\
\text { BSB }\end{array}$ \\
\hline & Area $\left(\mathrm{mm}^{2}\right)$ & 8400 \\
\hline \multirow[t]{3}{*}{ Shear connectors } & $\begin{array}{c}\text { Kind of } \\
\text { studs }\end{array}$ & $12.7 \times 50$ \\
\hline & $\begin{array}{l}\text { Distribution } \\
\text { of studs }\end{array}$ & $\begin{array}{l}\text { Uniform in } \\
\text { pairs }\end{array}$ \\
\hline & $\begin{array}{c}\text { Number of } \\
\text { studs }\end{array}$ & 100 \\
\hline $\begin{array}{l}\text { Longitudinal } \\
\text { reinforcement }\end{array}$ & Top $\left(\mathrm{mm}^{2}\right)$ & 200 \\
\hline
\end{tabular}

Table 2. Material properties of simply supported test beam E1

\begin{tabular}{|c|c|c|c|}
\hline $\begin{array}{c}\text { Beam } \\
\text { identification }\end{array}$ & $\begin{array}{c}\text { Compressive } \\
\text { Concrete } \\
\text { strength } \\
(\text { MPa })\end{array}$ & E1 \\
\hline & $\begin{array}{c}\text { Tensile } \\
\text { strength } \\
f_{c t}(\mathrm{MPa})\end{array}$ & & 32.7 \\
\hline & $\begin{array}{c}\text { Peak strain } \\
\text { in } \\
\text { compression } \\
\varepsilon_{c 1} 1\end{array}$ & $\begin{array}{c}\text { Peak strain } \\
\text { in tension } \\
\varepsilon_{c t 1}\end{array}$ & 0.0022 \\
\hline Steel & $\begin{array}{c}\text { Yield stress } \\
(\text { MPa })\end{array}$ & Flange & 250 \\
\hline & $\begin{array}{c}\text { Ultimate } \\
\text { tensile stress }\end{array}$ & Flange & 465 \\
\hline
\end{tabular}




\begin{tabular}{|c|c|c|c|}
\hline & (MPa) & & \\
\hline & & Web & 460 \\
\hline & & Rft & 320 \\
\hline & $\begin{array}{c}\begin{array}{c}\text { Strain } \\
\text { hardening }\end{array} \\
\text { strain } \varepsilon_{s h}\end{array}$ & Flange & 0.00267 \\
\hline & & Web & 0.00144 \\
\hline & $\begin{array}{l}\begin{array}{c}\text { Elasticity } \\
\text { modulus }\end{array} \\
E_{S}(\mathrm{MPa})\end{array}$ & & 206000 \\
\hline & $\begin{array}{c}\text { Strain- } \\
\text { hardening } \\
\text { modulus } \\
E_{s h}(\mathrm{MPa})\end{array}$ & & 3500 \\
\hline \multirow[t]{3}{*}{ Connection } & $Q_{u_{(\mathrm{kN})}}$ & & 66 \\
\hline & $\beta_{\left(\mathrm{mm}^{-1}\right)}$ & & 0.8 \\
\hline & $\alpha$ & & 0.45 \\
\hline
\end{tabular}

Table 3. Material properties of continuous test beam CTB4

\begin{tabular}{|c|c|c|c|}
\hline $\begin{array}{c}\text { Beam } \\
\text { identification }\end{array}$ & & & CTB4 \\
\hline \multirow[t]{4}{*}{ Concrete } & $\begin{array}{l}\text { Compressive } \\
\text { strength } f_{C} \\
(\mathrm{MPa})\end{array}$ & & 34 \\
\hline & $\begin{array}{c}\text { Tensile } \\
\text { strength } \\
f_{\text {ct }}(\mathrm{MPa})\end{array}$ & & 3.15 \\
\hline & $\begin{array}{c}\text { Peak strain } \\
\text { in } \\
\text { compression } \\
\varepsilon_{c 1}\end{array}$ & & 0.0022 \\
\hline & $\begin{array}{c}\text { Peak strain } \\
\text { in tension } \\
\varepsilon_{c t 1}\end{array}$ & & 0.00015 \\
\hline \multirow[t]{11}{*}{ Steel } & $\begin{array}{c}\text { Yield stress } \\
(\mathrm{MPa})\end{array}$ & Flange & 236 \\
\hline & & Web & 238 \\
\hline & & $\mathrm{Rft}$ & 430 \\
\hline & $\begin{array}{c}\text { Ultimate } \\
\text { tensile stress } \\
(\mathrm{MPa})\end{array}$ & Flange & 393 \\
\hline & & Web & 401 \\
\hline & & $\mathrm{Rft}$ & 533 \\
\hline & $\begin{array}{c}\text { Strain } \\
\text { hardening } \\
\text { strain } \varepsilon_{s h}\end{array}$ & Flange & 0.018 \\
\hline & & Web & 0.018 \\
\hline & & $\mathrm{Rft}$ & 0.01 \\
\hline & $\begin{array}{l}\text { Elasticity } \\
\text { modulus } \\
E_{S}(\mathrm{MPa})\end{array}$ & & 206000 \\
\hline & $\begin{array}{c}\text { Strain- } \\
\text { hardening } \\
\text { modulus }\end{array}$ & $\begin{array}{l}\text { Steel } \\
\text { beam }\end{array}$ & 3000 \\
\hline
\end{tabular}

\begin{tabular}{|c|c|c|c|}
\hline & $E_{s h_{(\mathrm{MPa})}}$ & & \\
\hline & & $\mathrm{Rft}$ & 3500 \\
\hline \multirow{2}{*}{ Connection } & $Q_{u(\mathrm{kN})}$ & & 110 \\
\hline & $\beta_{\left(\mathrm{mm}^{-1}\right)}$ & & 1.2 \\
\hline & $\alpha$ & & 0.85 \\
\hline
\end{tabular}

Table 4. Geometrical characteristics of continuous test beam CTB4

\begin{tabular}{|c|c|c|c|}
\hline $\begin{array}{l}\text { Span Length } \\
(\mathrm{mm})\end{array}$ & & & CTB4 \\
\hline Loading type & & & 4500 \\
\hline \multirow[t]{2}{*}{ Concrete slab } & & & $\begin{array}{c}\text { Midspan } \\
\text { point } \\
\text { load }\end{array}$ \\
\hline & $\begin{array}{l}\text { Thickness } \\
\text { (mm) }\end{array}$ & & 100 \\
\hline \multirow[t]{2}{*}{ Steel beam } & $\begin{array}{l}\text { Width } \\
\text { (mm) }\end{array}$ & & 800 \\
\hline & Section & & $\begin{array}{c}\text { HEA } \\
200\end{array}$ \\
\hline \multirow[t]{4}{*}{$\begin{array}{c}\text { Shear } \\
\text { connectors }\end{array}$} & Area $\left(\mathrm{mm}^{2}\right)$ & & 5380 \\
\hline & $\begin{array}{l}\text { Kind of } \\
\text { studs }\end{array}$ & & $19 \times 75$ \\
\hline & $\begin{array}{c}\text { Number of } \\
\text { studs }\end{array}$ & & 84 \\
\hline & $\begin{array}{c}\text { Pitch of } \\
\text { studs }(\mathrm{mm})\end{array}$ & Sag & 350 \\
\hline \multirow[t]{4}{*}{$\begin{array}{c}\text { Longitudinal } \\
\text { reinforcement }\end{array}$} & & Hog & 300 \\
\hline & $\begin{array}{c}\text { Hog top } \\
\left(\mathrm{mm}^{2}\right)\end{array}$ & & 804 \\
\hline & $\begin{array}{c}\text { Hog bottom } \\
\left(\mathrm{mm}^{2}\right)\end{array}$ & & 767 \\
\hline & $\begin{array}{c}\text { Sag top } \\
\left(\mathrm{mm}^{2}\right)\end{array}$ & & 160 \\
\hline $\begin{array}{l}\text { Span Length } \\
(\mathrm{mm})\end{array}$ & $\begin{array}{c}\text { Sag bottom } \\
\left(\mathrm{mm}^{2}\right)\end{array}$ & & 160 \\
\hline
\end{tabular}

\subsection{Effect of tension stiffening parameter}

In the present study, three values of the tension stiffening $0.01,0.05$ and 0.09 are used and it is found that for the simple composite beam tested by Chapman and Balakrishnan (1964) a total strain of 0.01 gives the best agreement with the experiment as shown in Figure 9, while for the continuous composite beam tested by Ansourian (1981) a total strain of 0.09 gives the best agreement with the experiment as shown in Figure 10. 


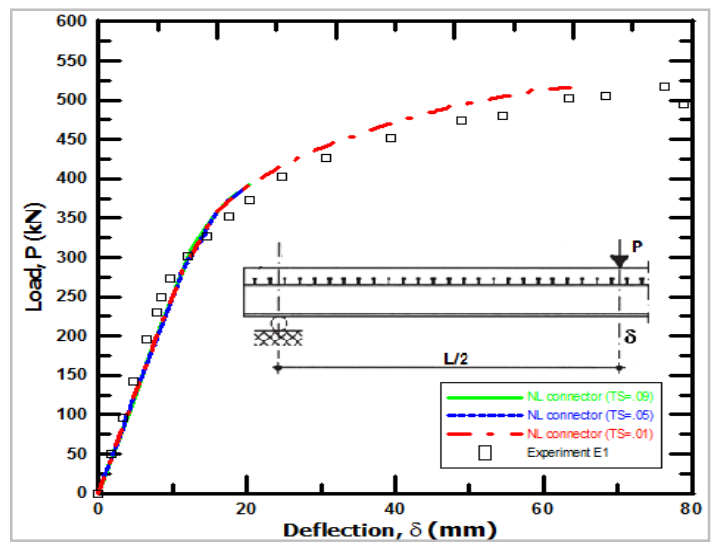

Fig 9: Effect of Tension Stiffening parameter (Beam E1 Chapman and Balakrishnan (1964))

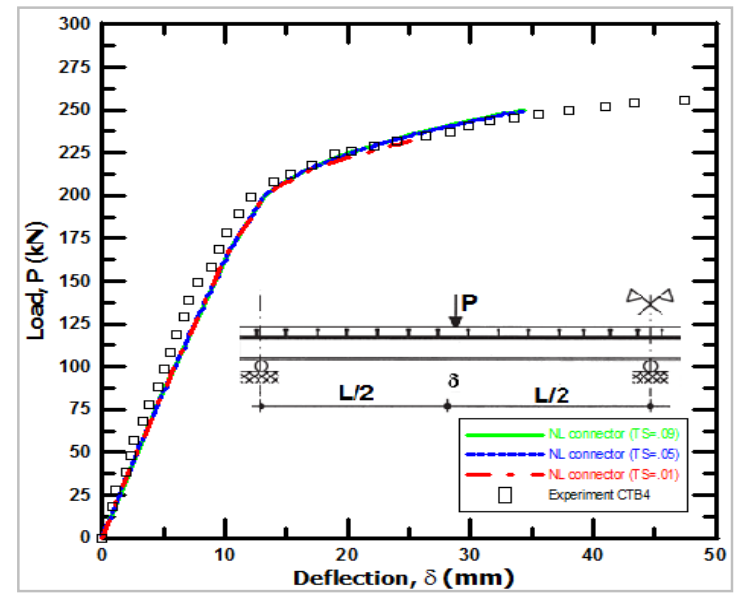

Fig 10: Effect of Tension Stiffening parameter (Beam CTB 4, Ansourian (1981))

\subsection{Validation of the connector elements}

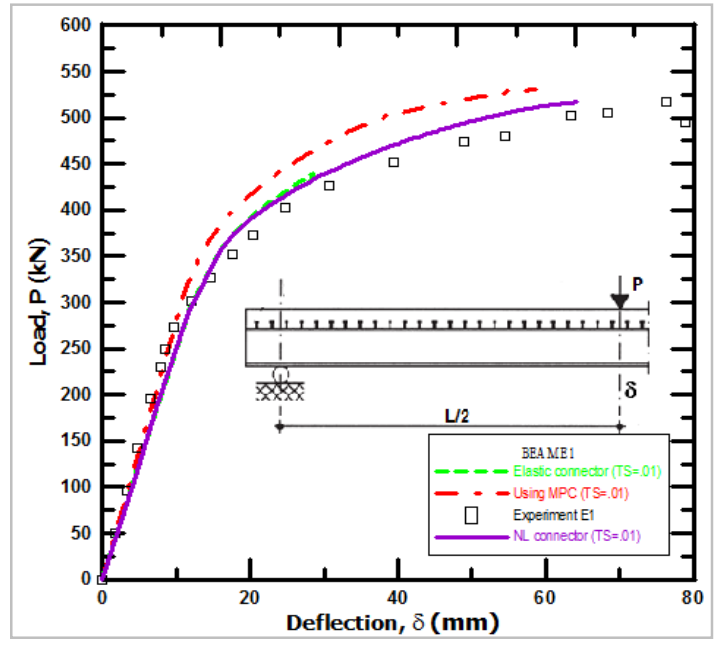

Fig 11: Effect of various modeling of shear connectors (Beam E1, Chapman and Balakrishnan (1964))

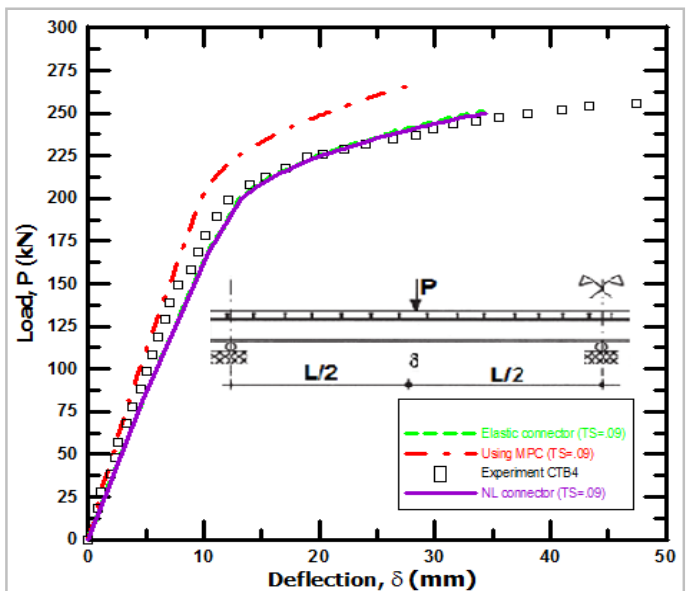

Fig 12: Effect of various modeling of shear connectors (Beam CTB 4, Ansourian (1981)

From the comparisons made with the experimental data it can be concluded that for full shear connection, using the General multi-points constraints (MPC constraints) gives a good solution for both beams E1 \& CTB 4, and for partial shear connection, using the Nonlinear elastic connector elements and Contact interactions gives the best agreement with the experiment as shown in Figures 11 and 12 for beams E1 \& CTB 4, respectively.

\subsection{Comparisons with published numerical studies}

The load-deflection curves of the composite beam E1 and of the composite beam CTB 4 obtained by the present study are compared with that obtained by experiment and with that obtained by alternative numerical studies, Gattesco (1999), El- Lobody and Lam (2003) as shown in Figures 13 and 14.

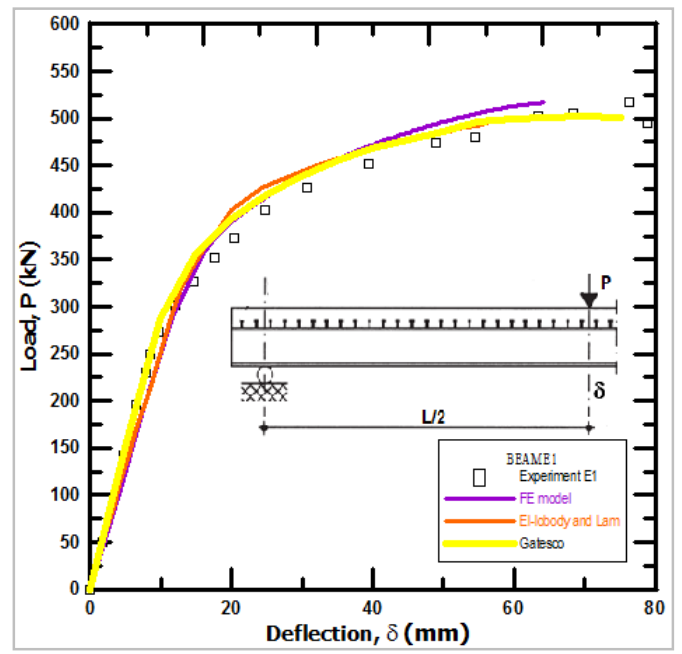

Fig 13: Validation of the finite element model (Beam E1 Chapman and Balakrishnan (1964)) 


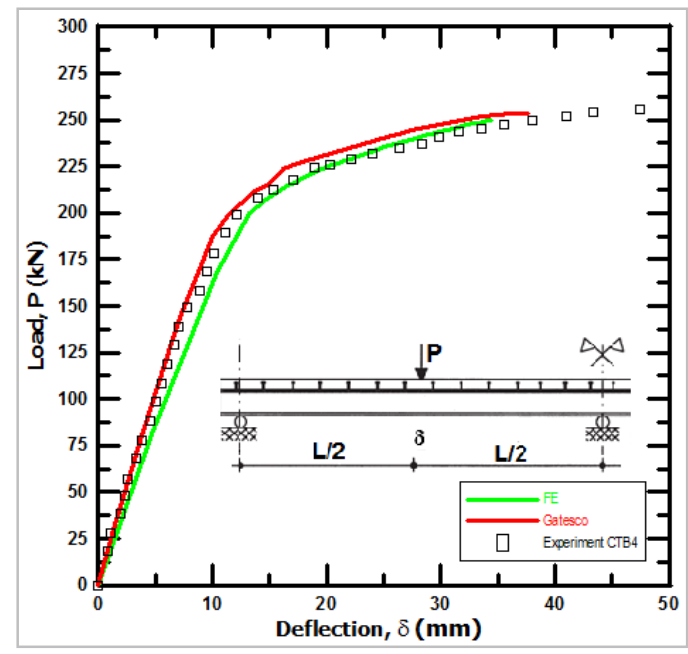

Fig 14: Validation of the finite element model ((Beam CTB 4, Ansourian (1981))

It can be observed from Figures 13 and 14 that the initial stiffness of the composite beams predicted by the present finite element model is the same as that of the experimental one. The ultimate load obtained by the present study is 517 $\mathrm{kN}$, which is $97 \%$ of the experimental value for beam E1 and $250 \mathrm{kN}$, which is $98 \%$ of the experimental value for beam CTB 4. The nonlinear finite element analysis conformed with the experimental observation that the composite beam E1 failed by crushing of the top concrete slab at midspan and the beam CTB 4 failed by crushing of the top concrete slab at midspan and at the middle support. It can be concluded that the present finite element model is reliable and conservative in predicting the ultimate strength of composite beams.

\section{PARAMETRIC STUDY}

Based on the previous experimental verification of the FE analysis, a parametric study on buckling of continuous steel concrete composite castellated beams in negative bending is further carried out to investigate the influence of different parameters on the strength, elastic stiffness and ductility of such beams. The ductility of the beams can be measured by the toughness ratio (TR) Dabaon (2002).

$$
T R=T_{u} / T_{e}
$$

Where, $T_{u}$ is the area under the ultimate curve of the load deflection relationship and $T_{e}$ is the area under the elastic curve as shown in Figure 15.

A total of 96 models are built and solved using ABAQUS. Only half length of the beam is modeled due to symmetry. The deflection at midspan of the composite castellated beams is monitored in the analysis. The shear connectors are designed according to the Eurocode 4 (1992), where the nominal stud strengths are given by:

$$
q_{n} \leq\left\{\begin{array}{c}
0.29 d^{2} f_{c k} E_{c m} 1 / 2 \\
0.8 f_{u}\left(\frac{\pi d^{2}}{4}\right)
\end{array}\right.
$$

where $d$ is the diameter of the shank of the stud, $f_{c k}$ is the characteristic cylinder strength of the concrete, $E_{c m}$ is the nominal value of the secant modulus of the concrete, $f_{u}$ is the specified ultimate tensile strength of the material of the stud but not greater than $500 \mathrm{~N} / \mathrm{mm}^{2}$.

Based on the composite section strength of the concrete slab, steel components and shear connectors, the level of shear

connection ${ }^{\eta}$ could be determined. This value is defined as the ratio between the shear connection capacity and the weakest element capacity (concrete slab or steel beam). The composite castellated beams are designed on a level of shear connection $\eta=1$, where the beams exhibit full shear connection (conformed by experimental findings presented by Donahey and Darwin (1986). There are three criteria used in the present study to define the ultimate load. These criteria are shear connector failure (by monitoring the slip of the studs), divergence (due to the large amounts of cracking) and distortional buckling of the beam web (Figure 16).

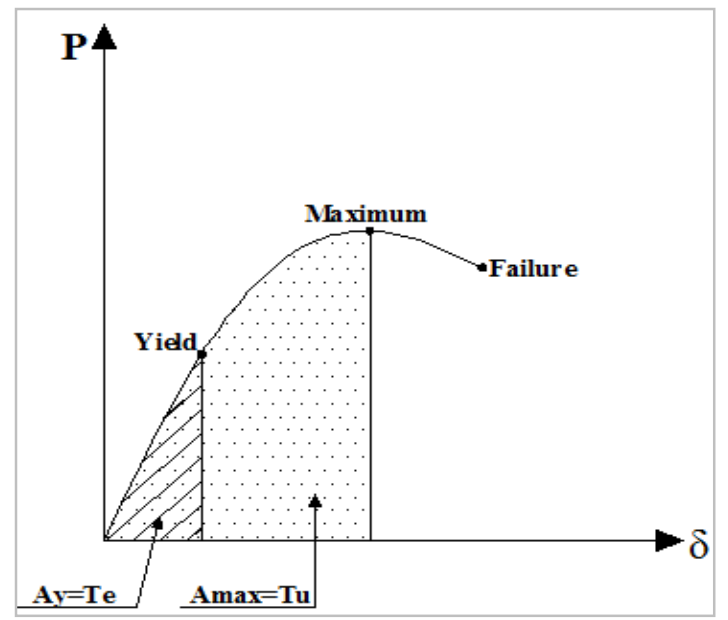

Fig 15: Definition of toughness ratio parameters, Dabaon (2002) 


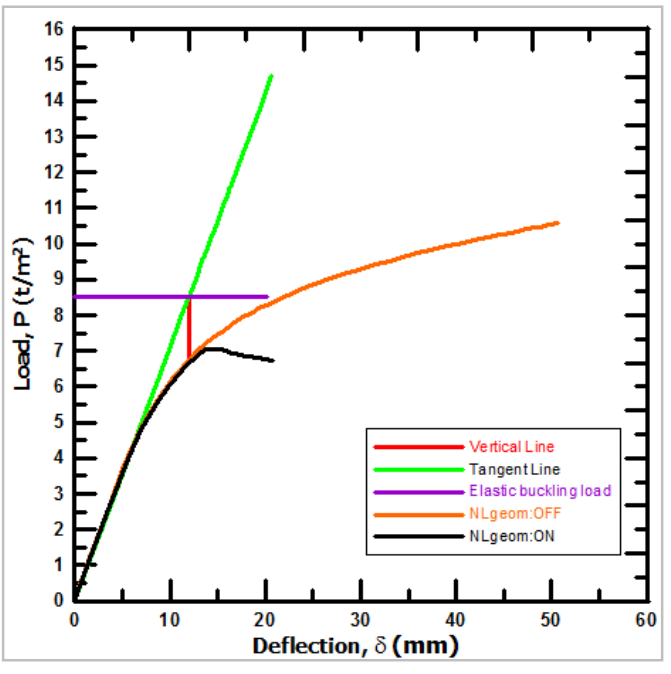

Fig 16: Buckling failure criteria

\subsection{Effect of web slenderness}

In this section, an investigation is performed to assess the sensitivity of the overall response of the composite beams (represented by the load-deflection curve) including the initial stiffness, the strength and the ductility to likely variations in web slenderness. Sample of the load deflection curves are shown in Figure 17.

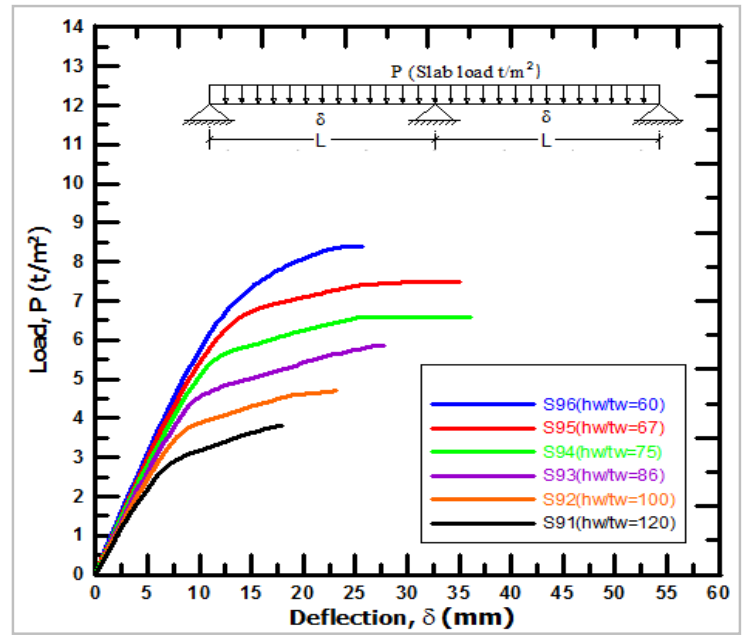

Fig 17: Load deflection curve of beams with $\left(L / h_{w}=12\right)$

It appears that by decreasing the web slenderness (through an increase in the web thickness), an increase in the ultimate load and initial stiffness is achieved. However, by decreasing the web slenderness the ductility also increases but only in the beams for which the failure is controlled by buckling, while for the beams for which the failure is controlled by concrete cracks or shear connector's failure, the ductility begins to decrease. These results were concluded after studying a number of beams varying in their span to depth ratio as illustrated in the following Figures 18, 19 and 20.

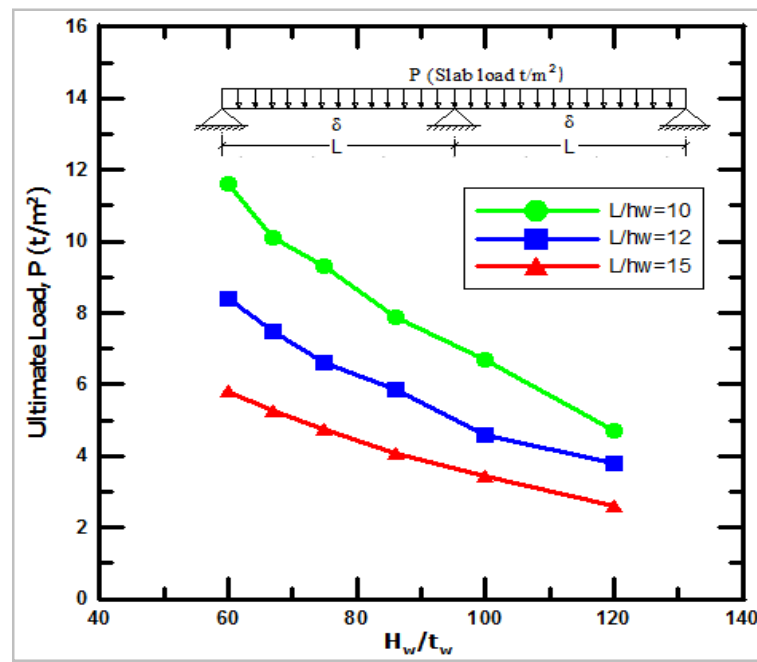

Fig 18: Effect of web slenderness on ultimate load for different $L / h_{w}$

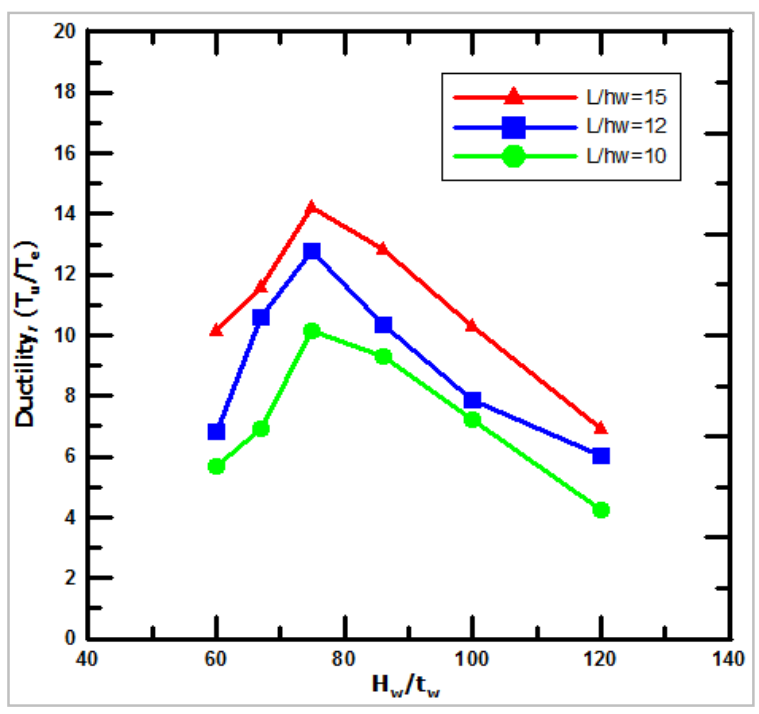

Fig 19: Effect of web slenderness on ductility for different $L / h_{w}$

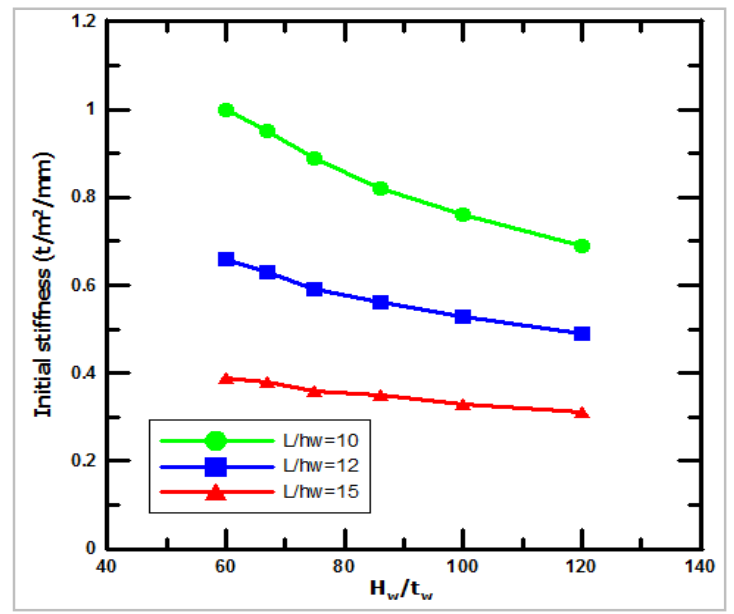

Fig 20: Effect of web slenderness on initial stiffness for different $L / h_{w}$ 
From the previous figures, it is clear that an increase in the ultimate load is achieved by decreasing the web slenderness, but the percentage of increase differs from one group to another. Starting from $h_{w} / t_{w}=120$ then $100,86,75,67$ and 60 , the percentages of increase in ultimate load for different subgroups are as follows: for $\left(\mathrm{L} / \mathrm{h}_{\mathrm{w}}=10\right), 42.6 \%, 67.4 \%$, $97.9 \%, 114.9 \%, 146.8 \%$ respectively. And for $\left(\mathrm{L} / \mathrm{h}_{\mathrm{w}}=15\right)$, these percentages decrease to be $32.4 \%, 57.9 \%, 83 \%, 103.5 \%$, 125.1 respectively. These results are logic, as by increasing span to depth ratio, the beams become weaker which results in a decrease in the ultimate load as shown in Figure 18. It is observed that the beams, having web slenderness $\left(\mathrm{h}_{\mathrm{w}} / \mathrm{t}_{\mathrm{w}}\right)$ more than (70-80), failed by steel web buckling, while the beams, having web slenderness less than (70-80), failed by concrete for different span to depth ratios. Also, as shown in Figure 19, beams with $\left(\mathrm{L} / \mathrm{h}_{\mathrm{w}}=15\right)$ behave ductile more than beams with $\left(\mathrm{L} / \mathrm{h}_{\mathrm{w}}=10\right)$. The ductility of beams with $\left(\mathrm{L} / \mathrm{h}_{\mathrm{w}}=12\right)$ is in between the two other groups which make sense with their span to depth ratios. From Figure 20, it can be concluded that the percentages of increase in the initial stiffness differs with the span to depth ratio. Table 5 summarizes the percentages of increase.

Table 5. Percentages of increase in the initial stiffness for different $h_{w} / t_{w}$

\begin{tabular}{|c|c|c|c|}
\hline $\begin{array}{c}\text { Web } \\
\text { slenderness } \\
\left(\mathrm{h}_{\mathrm{w}} / \mathrm{t}_{\mathrm{w}}\right)\end{array}$ & $\mathrm{L} / \mathrm{h}_{\mathrm{w}}=10$ & $\mathrm{~L} / \mathrm{h}_{\mathrm{w}}=12$ & $\mathrm{~L} / \mathrm{h}_{\mathrm{w}}=15$ \\
\hline 120 & ---- & ---- & ---- \\
\hline 100 & $10.1 \%$ & $8.2 \%$ & $6.5 \%$ \\
\hline 86 & $18.8 \%$ & $14.3 \%$ & $12.9 \%$ \\
\hline 75 & $29.0 \%$ & $20.4 \%$ & $16.1 \%$ \\
\hline 67 & $37.7 \%$ & $28.6 \%$ & $22.6 \%$ \\
\hline 60 & $44.9 \%$ & $34.7 \%$ & $28 \%$ \\
\hline
\end{tabular}

\subsection{Effect of changes in web geometry}

Three cases of the web are studied in addition to the normal castellated web in order to improve the buckling capacity of the continuous composite castellated beam; Figures 21-24 show the four cases of the web

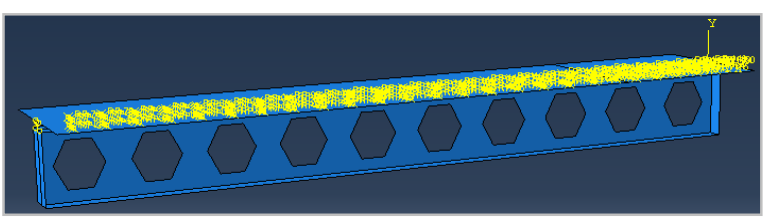

Fig 21: Web status A* (Castellated)

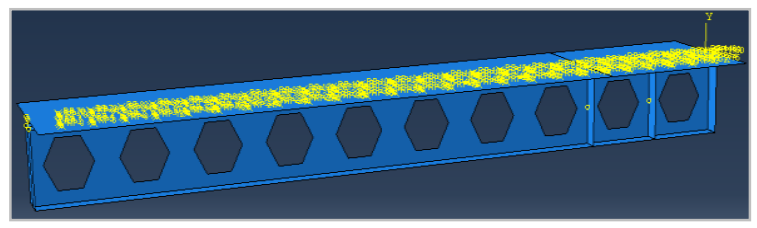

Fig 22: Web status B* (Vertical stiffeners)

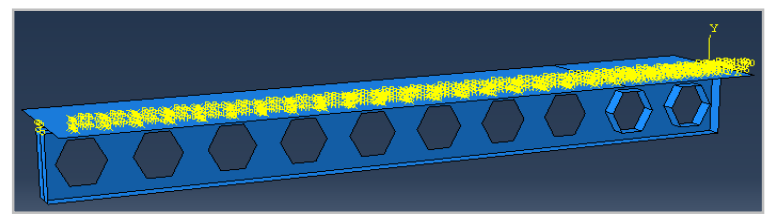

Fig 23: Web status $C^{*}$ (Stiffeners around openings)

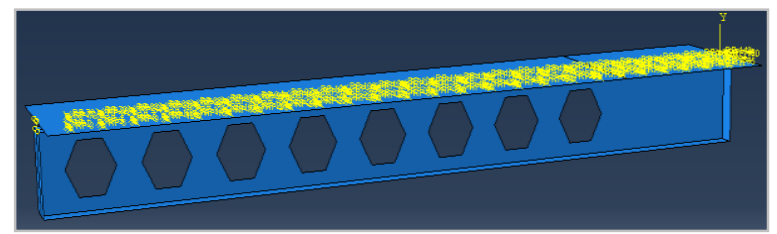

Fig 24: Web status $D^{*}$ (openings starting at fifth of span)

A number of beams varying in their span to depth ratios and web slenderness were studied to investigate the effect of the previous web statuses on the overall behavior of the continuous composite castellated beams. Samples of the load deflection curves are shown in figure 25 .

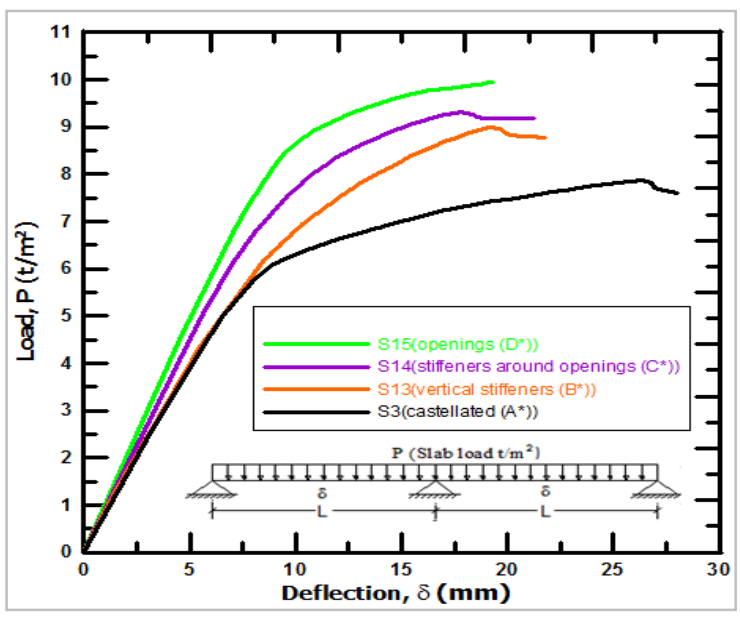

Fig 25: Load deflection curve of beams with $\left(L / h_{w}=10 \& h_{w} / t_{w}=86\right)$

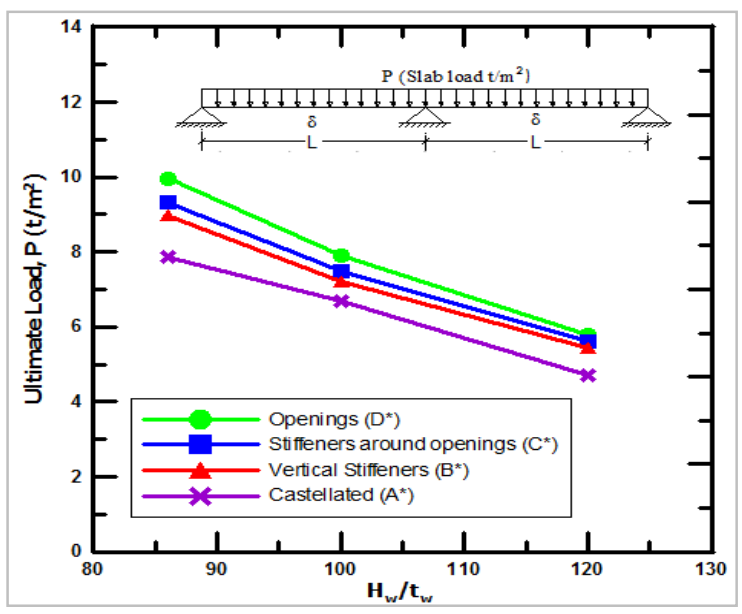

Fig 26: Effect of changes in web geometry on ultimate load for different $h_{w} / t_{w}$

The results show that the modifications made to the castellated web affected clearly the ultimate load, the ductility 
and the elastic stiffness of the composite beams. Starting the web openings after the negative moment region (Status $\mathrm{D}^{*}$ ) gives the highest ultimate load, followed by stiffeners around the openings in the negative moment region (Status $\mathrm{C}^{*}$ ), followed by using vertical stiffeners between the openings in the negative moment region (Status B*). For the ductility, beams with vertical stiffeners (Status $\mathrm{B}^{*}$ ) behave the most ductile. Regarding to the elastic stiffness, using vertical stiffeners (Status $\mathrm{B}^{*}$ ) approximately gives the same elastic stiffness as the normal castellated web (Status A*), while starting the web openings after the negative moment region (Status D*) gives a higher elastic stiffness, followed by using stiffeners around the openings (Status $C^{*}$ ). Figures 26-28 show the effect of the changes of the web on the ultimate load, ductility and initial stiffness on beams with different web slenderness with span to depth ratio $=10$.

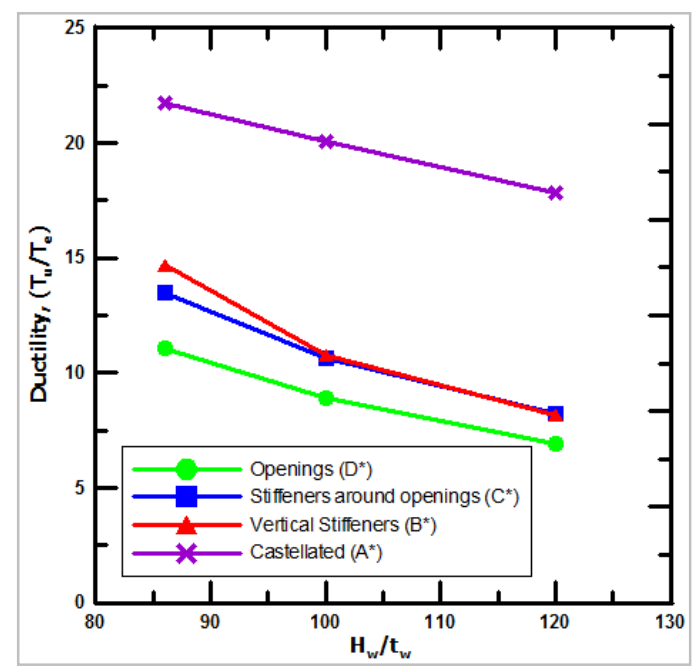

Fig 27: Effect of changes in web geometry on ductility for different $h_{w} / t_{w}$

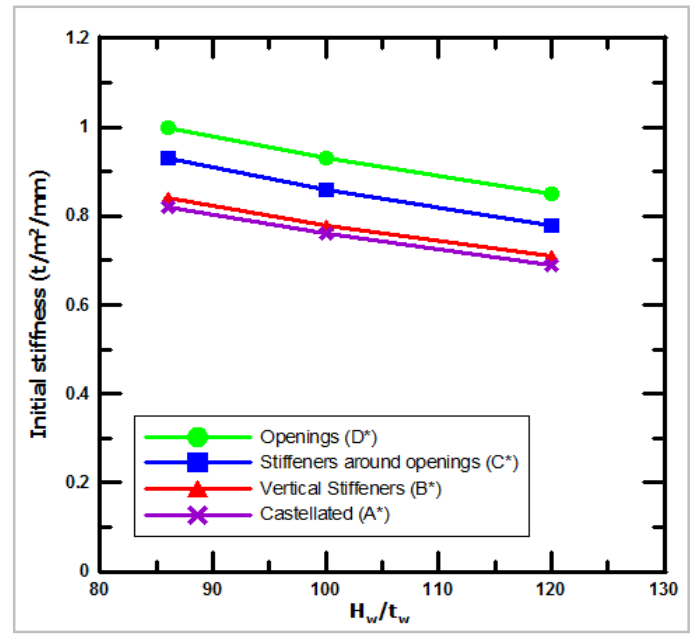

Fig 28: Effect of changes in web geometry on initial stiffness for different $h_{w} / t_{w}$

From Figure 26, we can conclude that the values of the ultimate loads that come from the three statuses of the castellated web $\left(\mathrm{B}^{*}, \mathrm{C}^{*}, \mathrm{D}^{*}\right)$ become closer to each other as the web slenderness increases and vice versa by decreasing the web slenderness. As an example on the percentages of increase in the ultimate loads achieved, for $h_{w} / t_{w}=100$, using vertical stiffeners causes an increase of ultimate load by $7.5 \%$, using stiffeners around openings causes an increase by $11.6 \%$ and starting the web openings after the negative moment region causes an increase by $17.8 \%$.From Figure 27, it is clear that using vertical stiffeners, stiffeners around openings and starting the web openings after the negative moment region affects clearly the ductility of the normal castellated beams, as the three cases $\left(\mathrm{B}^{*}, \mathrm{C}^{*}, \mathrm{D}^{*}\right)$ causes an obvious decrease in ductility less than the normal case (A*) by $43.7 \%, 45.8 \%$ and $54.9 \%$ respectively in the average with respect to different web slenderness. From Figure 28, we can conclude that starting the web openings after the negative moment region gives high values for the initial stiffness followed by using stiffeners around openings, while using vertical stiffeners gives low percentages of increase, so it is not recommended when high initial stiffness is required. As an example on the percentages of increase in the initial stiffness achieved, for $\mathrm{h}_{\mathrm{w}} / \mathrm{t}_{\mathrm{w}}=100$, using vertical stiffeners causes an increase by $2.6 \%$, using stiffeners around openings causes in an increase by $13.2 \%$ and starting the web openings after the negative moment region causes an increase by $22.4 \%$.As a kind of comparison between the results obtained for the beams with span to depth ratio=10 \& 15 , it is found that the percentages of increase in the ultimate loads that were gained from using vertical stiffeners, stiffeners around openings \& starting the openings after negative bending moment region are higher for the beams with span to depth ratio $=15\left(\mathrm{~L} / \mathrm{h}_{\mathrm{w}}=15\right)$ for the beams with high web slenderness. This means that when there is high probability that the buckling of the web controls the failure (in case of high web slenderness and high span to depth ratio), these solutions are more effective.

\subsection{Comparison between changes in web geometry and changes in web slenderness}

Improving the buckling capacity of the composite beams was the target either by decreasing the web slenderness or through the changes that were made in the web geometry. In this section, we are trying to compare the effectiveness of both solutions. Table 6 shows the increase in ultimate loads that were obtained from both solutions for specimens S1 to S4 $\left(\mathrm{L} / \mathrm{h}_{\mathrm{w}}=10\right)$.

Table 6. Different ultimate loads for $\mathrm{S1}-\mathrm{S} 4\left(\mathrm{~L} / \mathrm{h}_{\mathrm{w}}=10\right)$

\begin{tabular}{|c|c|c|c|c|c|}
\hline Specimen & $\mathrm{h}_{\mathrm{w}} / \mathrm{t}_{\mathrm{w}}$ & \multicolumn{4}{|c|}{$\mathrm{Pu}\left(\mathrm{t} / \mathrm{m}^{2}\right)$} \\
\hline & & $\left(\mathrm{A}^{*}\right)$ & $\left(\mathrm{B}^{*}\right)$ & $\left(\mathrm{C}^{*}\right)$ & $\left(\mathrm{D}^{*}\right)$ \\
\hline $\mathrm{S} 1$ & 120 & 4.7 & 5.43 & 5.61 & 5.8 \\
\hline $\mathrm{S} 2$ & 100 & 6.7 & 7.2 & 7.48 & 7.89 \\
\hline $\mathrm{S} 3$ & 86 & 7.87 & 8.98 & 9.31 & 9.94 \\
\hline $\mathrm{S} 4$ & 75 & 9.3 & ---- & ---- & --- \\
\hline
\end{tabular}

It is shown that by decreasing the web slenderness from 120 to 100 causes in an increase in the ultimate load by $42.6 \%$, while solutions $\mathrm{B}^{*}, \mathrm{C}^{*} \& \mathrm{D}^{*}$ causes an increase by $15.5 \%$, $19.4 \%, 23.4 \%$ respectively for $\mathrm{S} 1$. Then by decreasing the web slenderness from 100 to 86 causes an increase in the ultimate load by $17.5 \%$, while solutions B*, C* \& D* causes an increase by $7.5 \%, 11.6 \%, 17.8 \%$ respectively for S2.Finally by decreasing the web slenderness from 86 to 75 increases the ultimate load by $18.2 \%$, while solutions $\mathrm{B}^{*}, \mathrm{C}^{*}$ $\& D^{*}$ increases the ultimate load by $14.1 \%, 18.3 \%, 26.3 \%$ 
respectively for S3.From these results we can conclude that for high web slenderness $\left(h_{w} / t_{w}=120\right)$ improving the buckling capacity by decreasing the web slenderness from 120 to 100 is more effective than using solutions $\mathrm{B}^{*}, \mathrm{C}^{*} \& \mathrm{D}^{*}$. However, for $h_{w} / t_{w}=100$, using solution $D^{*}$ is more effective than decreasing the web slenderness from 100 to 86 . While for $\mathrm{h}_{\mathrm{w}} / \mathrm{t}_{\mathrm{w}}=86$, using solutions $\mathrm{C}^{*} \& \mathrm{D}^{*}$ are more effective than decreasing the web slenderness from 86 to 75 . Regarding to the ductility, it was shown in section 4.2 that the ductility of the three solutions $\mathrm{B}^{*}, \mathrm{C}^{*} \& \mathrm{D}^{*}$ is poor compared to the normal castellated beam $\mathrm{A}^{*}$ so we can conclude that improving the buckling capacity by decreasing the web slenderness is the best solution from ductility point of view. Regarding to the initial stiffness, table 7 shows the values of initial stiffness that are obtained from both solutions for beams S1 to $\mathrm{S} 4\left(\mathrm{~L} / \mathrm{h}_{\mathrm{w}}=10\right)$.

Table 7. Different initial stiffness for $\mathrm{S} 1-\mathrm{S} 4\left(\mathrm{~L} / \mathrm{h}_{\mathrm{w}}=10\right)$

\begin{tabular}{|c|c|c|c|c|c|}
\hline Specimen & $\mathrm{h}_{\mathrm{w}} / \mathrm{t}_{\mathrm{w}}$ & \multicolumn{4}{|c|}{ Initial stiffness $\left(\mathrm{t} / \mathrm{m}^{2} / \mathrm{mm}\right)$} \\
\hline & & $\left(\mathrm{A}^{*}\right)$ & $\left(\mathrm{B}^{*}\right)$ & $\left(\mathrm{C}^{*}\right)$ & $\left(\mathrm{D}^{*}\right)$ \\
\hline $\mathrm{S} 1$ & 120 & 0.69 & 0.71 & 0.78 & 0.85 \\
\hline $\mathrm{S} 2$ & 100 & 0.76 & 0.78 & 0.86 & 0.93 \\
\hline $\mathrm{S} 3$ & 86 & 0.82 & 0.84 & 0.93 & 1 \\
\hline $\mathrm{S} 4$ & 75 & 0.89 & ---- & ---- & --- \\
\hline
\end{tabular}

It is shown that by decreasing the web slenderness from 120 to 100 increases the initial stiffness by $10 \%$, while solutions $\mathrm{B}^{*}, \mathrm{C}^{*} \& \mathrm{D}^{*}$ results in an increase by $2.9 \%, 13 \%, 23 \%$ respectively for $\mathrm{S} 1$. Then by decreasing the web slenderness from 100 to 86 results in an increase in the initial stiffness by $7.89 \%$, while solutions $\mathrm{B}^{*}, \mathrm{C}^{*} \& \mathrm{D}^{*}$ results in an increase by $2.6 \%, 13 \%, 22 \%$ respectively for S2. Finally by decreasing the web slenderness from 86 to 75 results in an increase in the initial stiffness by $8.5 \%$, while solutions $\mathrm{B}^{*}, \mathrm{C}^{*} \& \mathrm{D}^{*}$ results in an increase by $2.4 \%, 13.4 \%, 21.9 \%$ respectively for $\mathrm{S} 3$. From these results we can conclude that for different web slenderness and different span to depth ratios, using solution $\mathrm{B}^{*}$ has insignificant influence on increasing the initial stiffness and decreasing the web slenderness is better than this solution. While the other two solutions are better than decreasing the web slenderness as they give higher percentages of increase in the initial stiffness starting with solution $\mathrm{D}^{*}$ and followed by solution $\mathrm{C}^{*}$.

\subsection{Effect of material properties}

The beams that were built and solved in order to investigate the effect of material properties are chosen on the basis of studding the effect on two categories, first one is on status A* (the normal castellated beams) and second one is on the status $D^{*}$ (starting the web openings after the negative moment region) as a proposed solution to enhance the buckling capacity for beams with different web slenderness and span to depth ratios.

\subsubsection{Effect of steel strength}

Variation in the value of yield and ultimate stresses (conforming to EC3 (2007)) is used to study the effect of the steel strength utilized in the steel beams. Samples of the load deflection curves for beams with span to depth ratio $=15$ are shown in figures 29 and 30. It is found that the variation of steel strength is very effective in improving the behavior of the composite castellated beams in the plastic stage (the start of yielding and the value of ultimate load), while there is no change in the initial stiffness which depends on the constant modulus of elasticity.

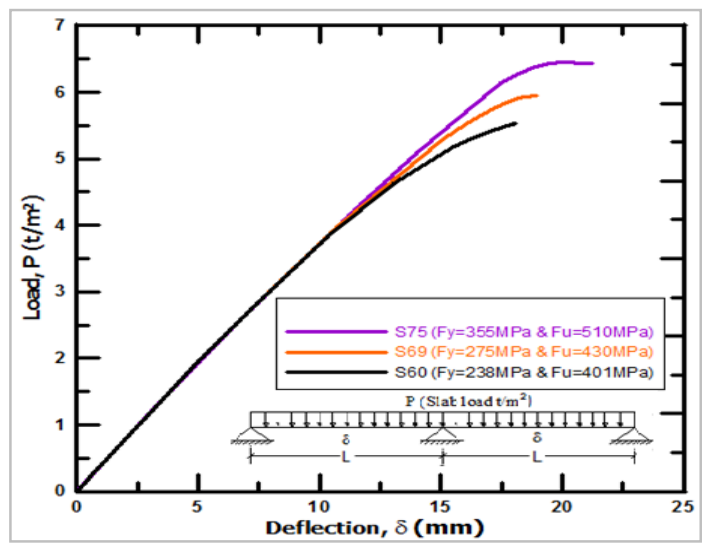

Fig 29: Load deflection curve of S60, S69 \& S75 $\left(L / h_{w}=15 \& h_{w} / t_{w}=86\right.$, web status $\left.D^{*}\right)$

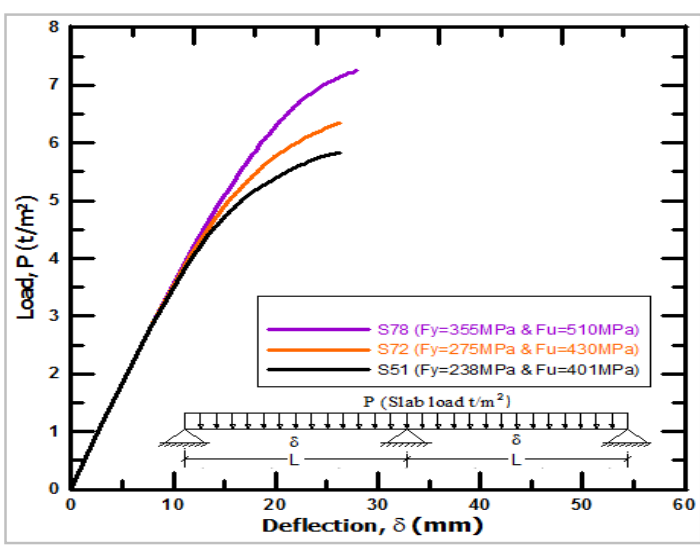

Fig 30: Load deflection curve of S51, $\mathrm{S} 72 \& \mathrm{S78}\left(\mathrm{L} / \mathrm{h}_{\mathrm{w}}=15\right.$ $\& h_{w} / t_{w}=60$, web status $A^{*}$ )

For different web slenderness, the effect of changes in steel strength on the ultimate load is shown in Figures 31 and 32, where there is an obvious increase in the ultimate load resulted from increasing the steel strength. As an example, for $\mathrm{h}_{\mathrm{w}} / \mathrm{t}_{\mathrm{w}}=86$ (web status $\mathrm{D}^{*}$ ), the percentage of increase in the ultimate load is $7.6 \%$ and $16.6 \%$ for type 2 and type 3 respectively, and for $h_{w} / t_{w}=60$ (web status $A^{*}$ ), the percentage of increase in the ultimate load is $8.7 \%$ and $24.4 \%$ for type 2 and type 3 respectively. 


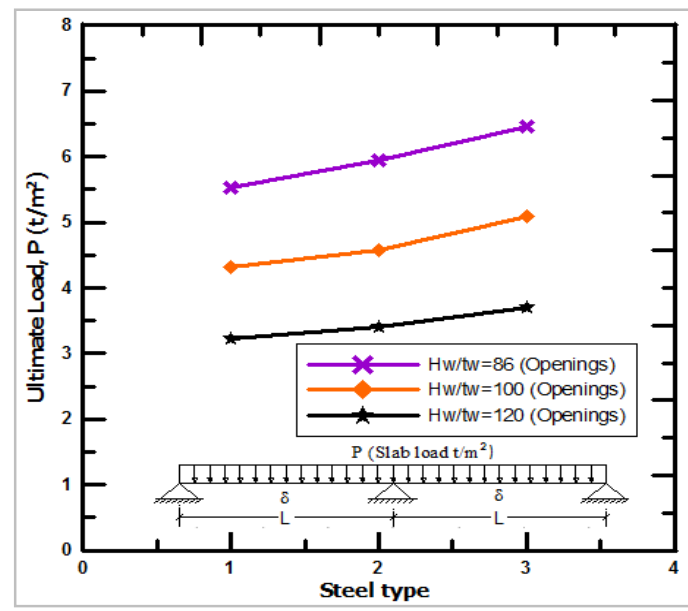

Fig 31: Effect of changes in steel strength on ultimate load (Beams with $L / h_{w}=15 \&$ web status $D^{*}$ )

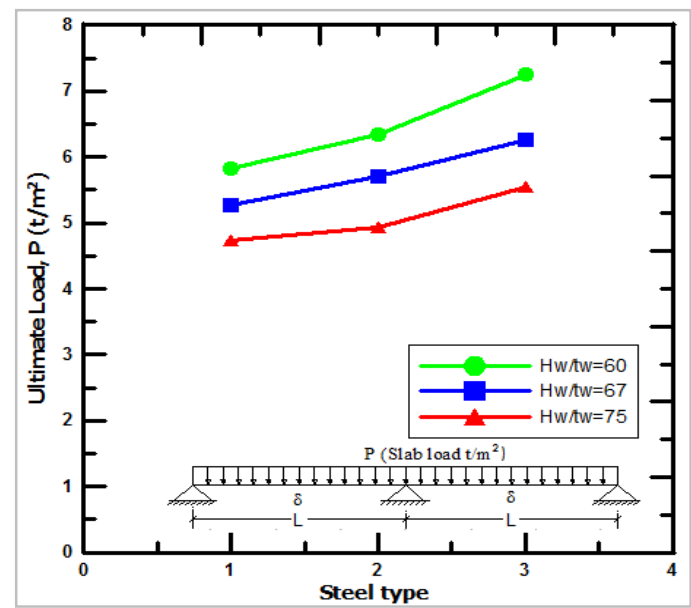

Fig 32: Effect of changes in steel strength on ultimate load (Beams with $\mathrm{L} / \mathrm{h}_{\mathrm{w}}=15 \&$ web status $\mathrm{A} *$ )

The effect of changes in steel strength on the ductility is shown in Figures 33 and 34, where the ductility decreases by increasing the steel strength in average by $15 \%$ and $30 \%$ for steel types $2 \& 3$, respectively.

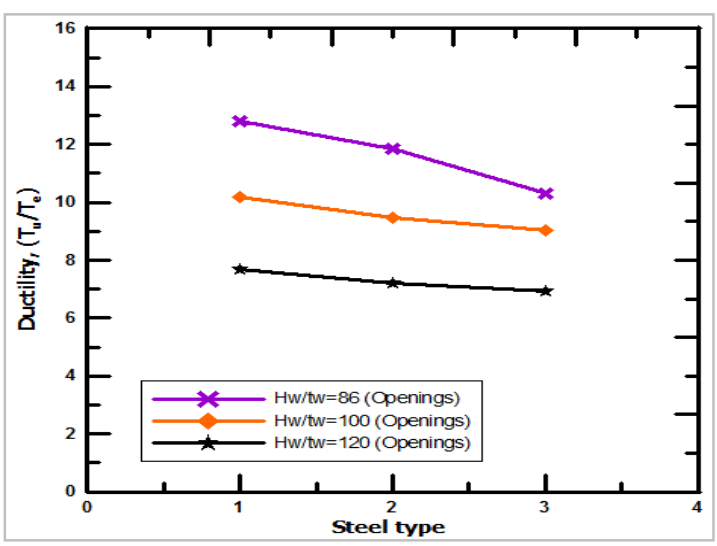

Fig 33: Effect of changes in steel strength on ductility (Beams with $L / h_{w}=15$ \& web status $D^{*}$ )

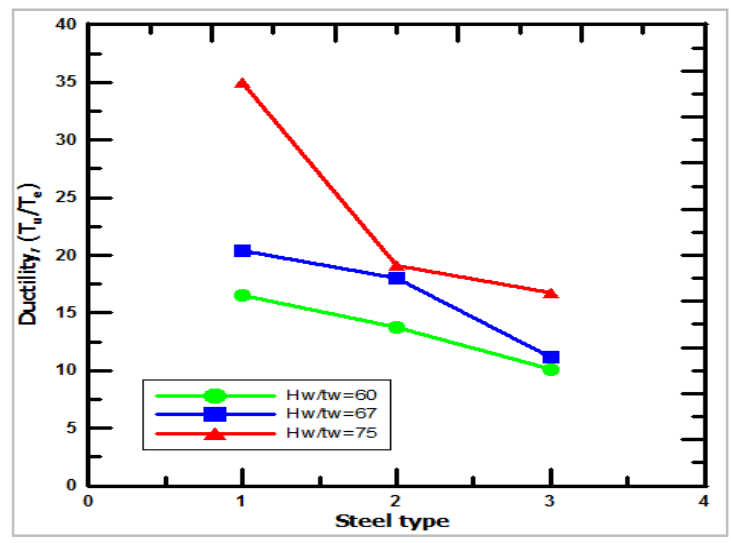

Fig 34: Effect of changes in steel strength on ductility (Beams with $L / h_{w}=15 \&$ web status $A^{*}$ )

From Figure 34, it can be noticed that the beams with $\mathrm{h}_{\mathrm{w}} / \mathrm{t}_{\mathrm{w}}=60$ behave less ductile than the specimens with $\mathrm{h}_{\mathrm{w}} / \mathrm{t}_{\mathrm{w}}=67$ and 75 which can be explained on the basis that by decreasing the web slenderness, the failure is no longer controlled by web buckling of the castellated beams but it is controlled by concrete slab failure on the contrary to what happened to the beams with $h_{w} / t_{w}=120,100$ and 86 in Figure 33 , where the ductility increases by decreasing the web slenderness due to web buckling failure.

Also it can be concluded that the web slenderness is insignificant with increasing the steel strength as the percentages of increasing the ultimate load resulted from increasing the steel strength are almost the same for different web slenderness and this can be illustrated in Figure 35.

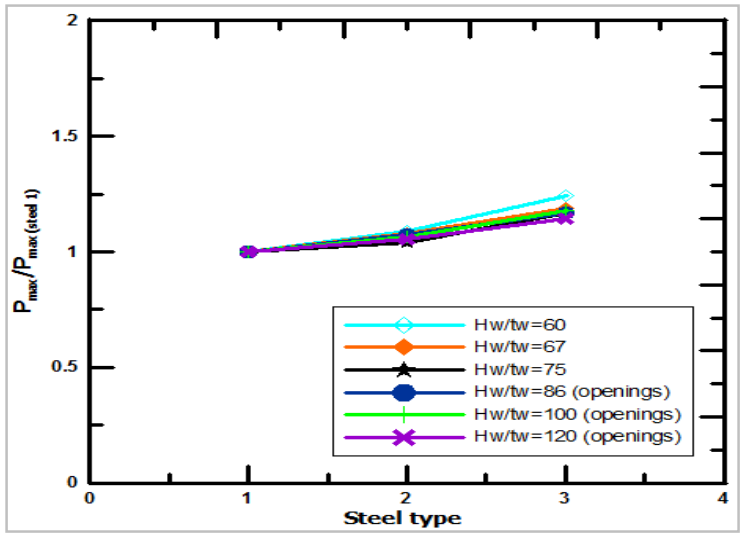

Fig 35: Load ratio versus steel type for different web slenderness

\subsubsection{Effect of concrete strength}

This parameter is studied through the use of different concrete compressive strengths $(34 \& 40 \mathrm{MPa})$ in the slab and in the associated push-out tests represented by the load-slip curves of shear connectors. Concrete strength of $34 \mathrm{MPa}$, which was used in the verified experiments, is used in the parametric study with the corresponding load-slip curve shown before in Figure 6. The load-slip curve of the shear connectors for concrete strength of $40 \mathrm{MPa}$ is shown in Figure 36, Mashaly et. al. (2010). It is noticeable that the strengths of these shear connectors are controlled by the concrete strength only whereas the other parameters of shear connectors were constant. 


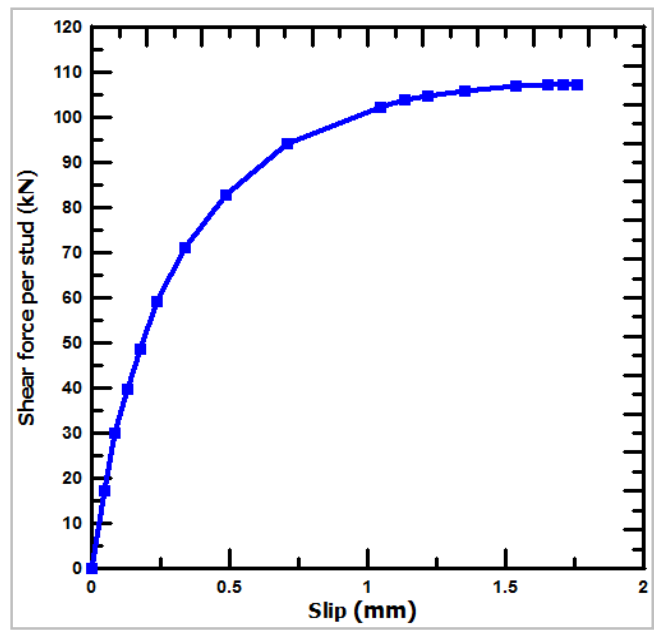

Fig 36: Load slip curve of the shear connectors for $F_{\text {cu }}$ of $40 \mathrm{MPa}$, Mashaly et. al. (2010)

Samples of the load deflection curves for beams with span to depth ratio $=15$ are shown in figures 37 and 38 . As shown in the load deflection curves, the variation of concrete strength has almost no influence on the initial stiffness, while we can achieve a small increase in the strength and ductility by increasing the concrete strength.

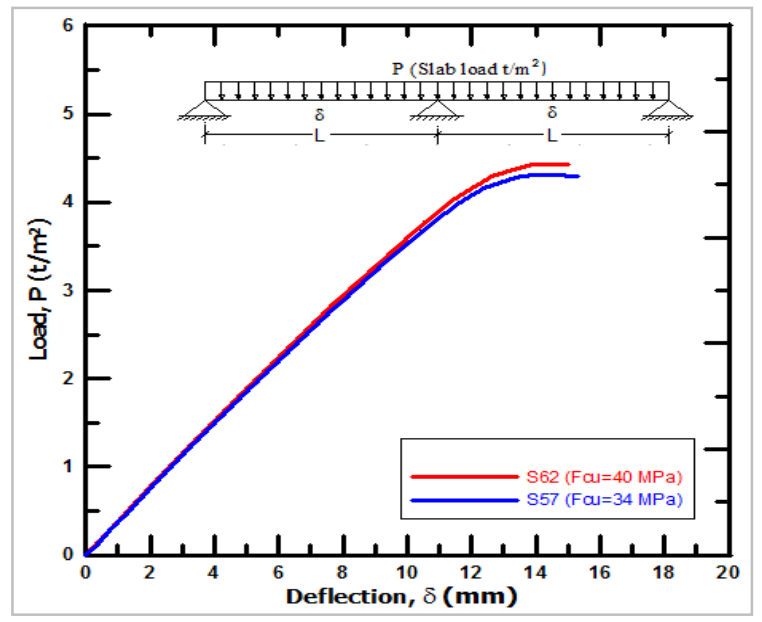

Fig 37: Load deflection curve of S57 \& S62 $\left(L / h_{w}=15 \& h_{w} / t_{w}=100\right.$, web status $\left.D^{*}\right)$

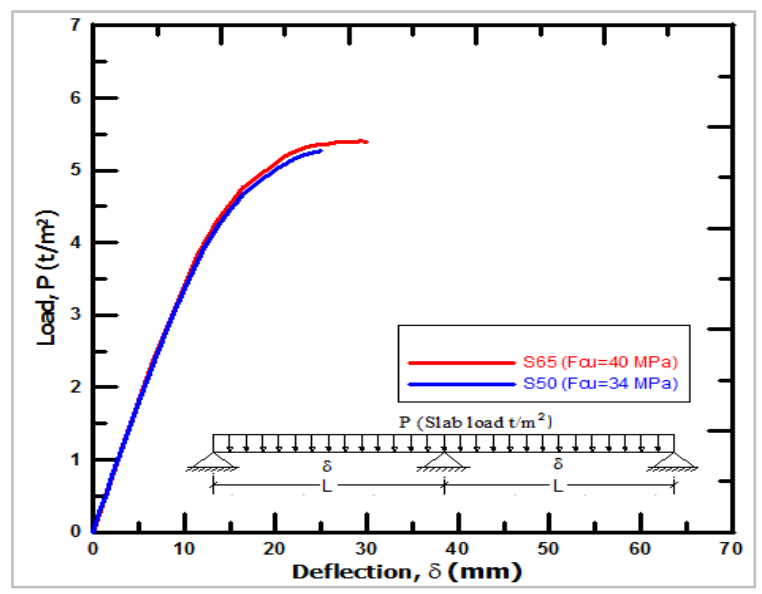

Fig 38: Load deflection curve of S50 \& $\mathrm{S65}\left(\mathrm{L} / \mathrm{h}_{\mathrm{w}}=15 \&\right.$ $h_{w} / t_{w}=67$, web status $\left.A *\right)$
The effect of concrete strength on the ultimate load is shown in Figures 39 and 40 where there are a small increase in the ultimate load resulted from increasing the concrete strength from $34 \mathrm{MPa}$ to $40 \mathrm{MPa}$ and some beams show no increase. As an example, for $h_{w} / t_{w}=100$ (web status $D^{*}$ ), the percentage of increase in the ultimate load is $3 \%$, and for $\mathrm{h}_{\mathrm{w}} / \mathrm{t}_{\mathrm{w}}=67$ (web status $\mathrm{A}^{*}$ ), the percentage of increase in the ultimate load is $2.5 \%$.

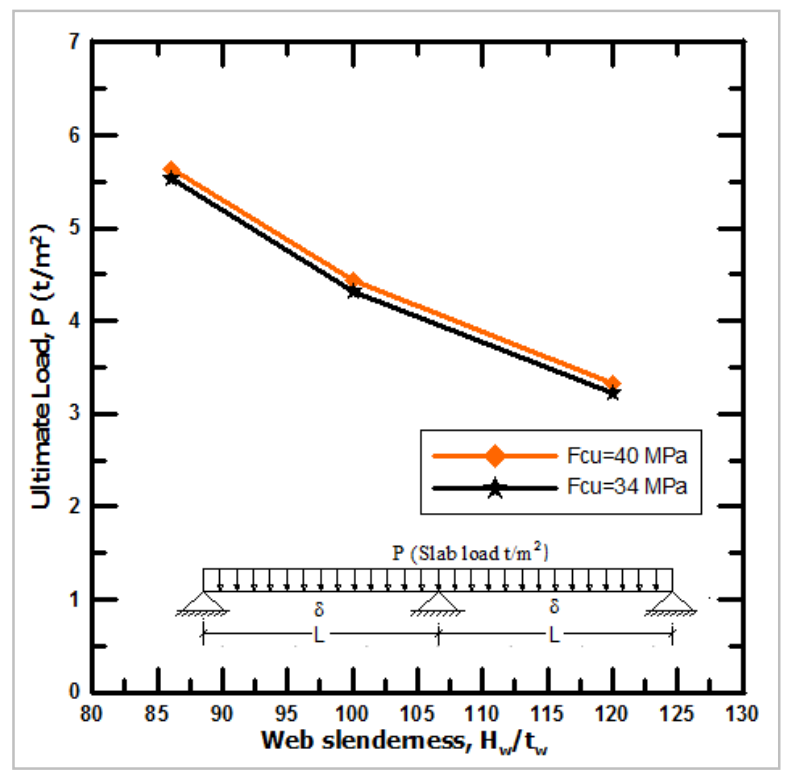

Fig 39: Effect of changes in concrete strength on ultimate load (Specimens with $L / h_{w}=15 \&$ web status $D^{*}$ )

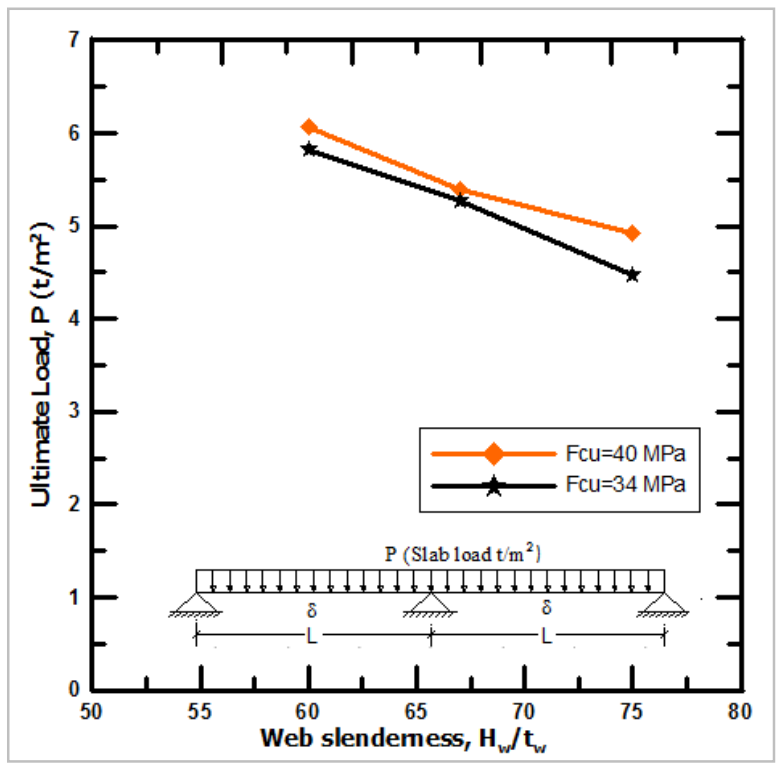

Fig 40: Effect of changes in $F_{\text {cu }}$ on ultimate load (Specimens with $L / h_{w}=15 \&$ web status $A^{*}$ )

Regarding to the ductility, Figures 41 and 42 show the effect of concrete strength, where for beams with web status $\mathrm{D}^{*}$, the increase in ductility is small and some beams show no increase. While for beams with web status $A^{*}$, the percentage of increase in the ductility resulted from increasing the 
concrete strength from $34 \mathrm{MPa}$ to $40 \mathrm{MPa}$ was $22 \%$ in average for the specimens with span to depth ratio $=15$.

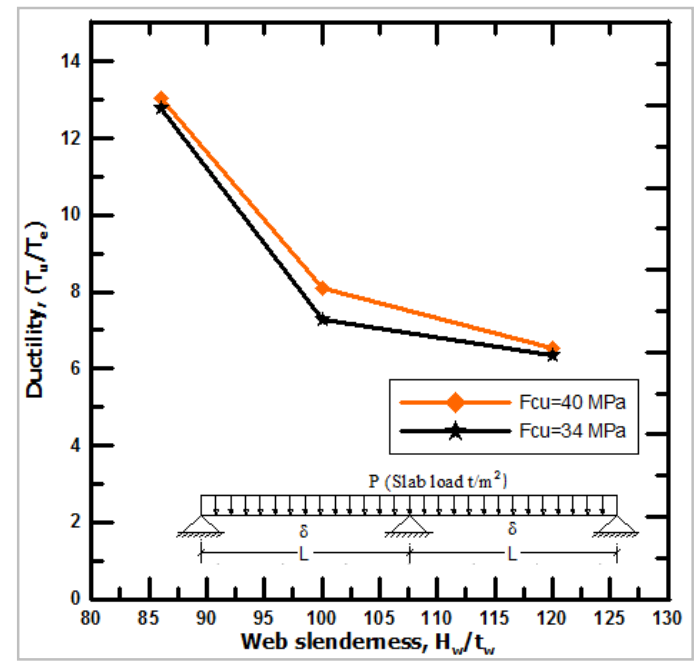

Fig 41: Effect of changes in concrete strength on ductility (Specimens with $L / h_{w}=15 \&$ web status $D^{*}$ )

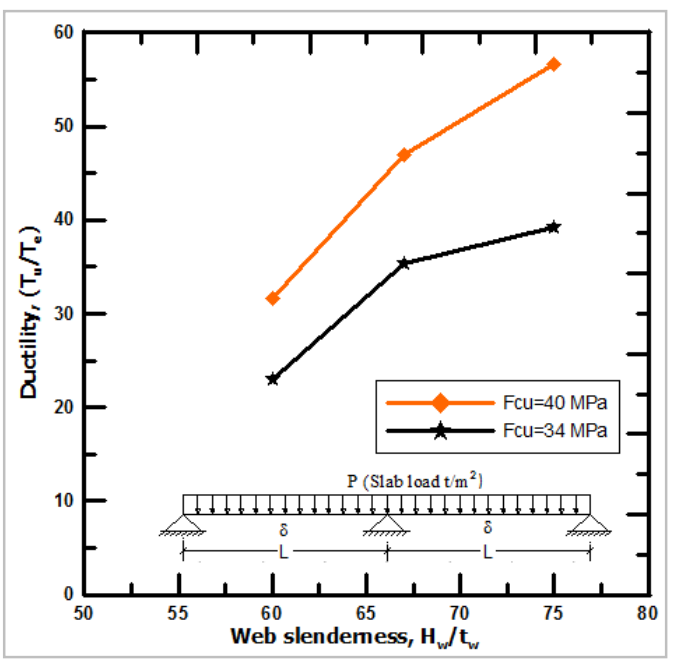

Fig 42: Effect of changes in concrete strength on ductility (Specimens with $\mathbf{L} / \mathrm{h}_{\mathrm{w}}=15$ \& web status $\mathrm{A}^{*}$ )

From Figure 42 it can be seen that the beams with $h_{w} / t_{w}=60$ behave the least ductile one as its failure is no longer controlled by buckling and these results are consistent to what were obtained in the previous section. From the previous results, it is found that there is no significant difference between the beams with different span to depth ratio and web statuses in regard to the effect of concrete strength as all beams almost show small increase in the ultimate load. While there is a difference in the behavior of the normal castellated beam $\left(A^{*}\right)$ and the beams with changes in web geometry $\left(B^{*}\right.$, $\left.\mathrm{C}^{*} \& \mathrm{D}^{*}\right)$ in regard to the ductility, as the ductility of the normal castellated beam $\left(\mathrm{A}^{*}\right)$ is significantly increased by increasing the concrete strength compared to the other beams $\left(\mathrm{B}^{*}, \mathrm{C}^{*} \& \mathrm{D}^{*}\right)$ which their increase is comparatively lower.

\subsection{Effect of concrete slab thickness}

In this study, the effect of the variation of the concrete slab thickness is studied. As done in the previous sections, the beams that are built and solved, in order to investigate this effect, are with web statuses A* and D*. Samples of the load deflection curves for beams with span to depth ratio $=15$ are shown in figures 43 and 44 . As shown in the load deflection curves, the variation of concrete slab thickness affected clearly the ultimate load, the ductility, and the initial stiffness as will be explained.

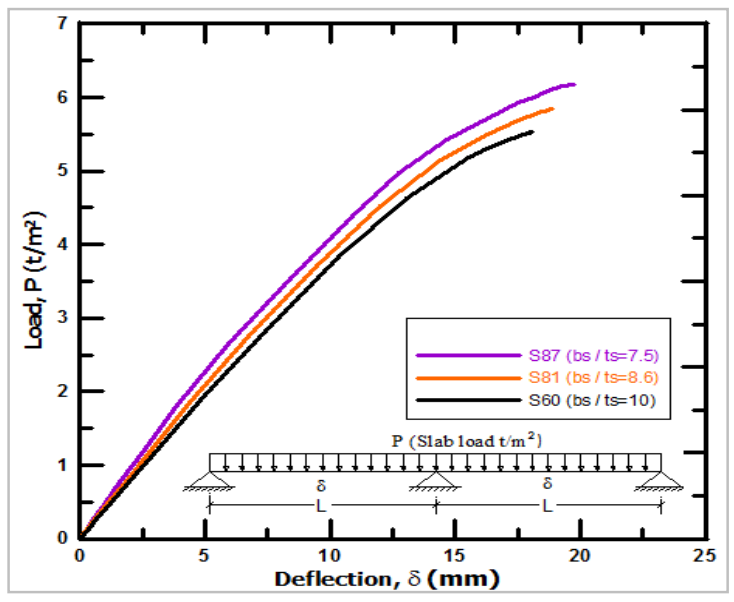

Fig 43: Load deflection curve of S60, S81 \& S87 $\left(L / h_{w}=15 \& h_{w} / t_{w}=86\right.$, web status $\left.D^{*}\right)$

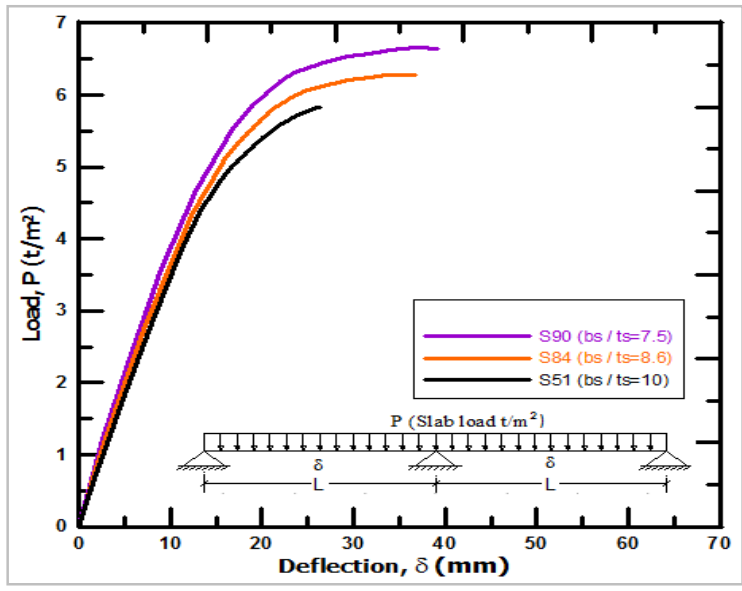

Fig 44: Load deflection curve of $S 51, S 84 \& S 90\left(L / h_{w}=15\right.$ $\& h_{w} / t_{w}=60$, web status $\left.A^{*}\right)$

The effect of slab thickness on the ultimate load is shown in figures 45 and 46, where there is an obvious increase in the ultimate load resulted from increasing the slab depth. For example, starting from $b_{s} / t_{s}=10$, for $h_{w} / t_{w}=86$ (web status $D^{*}$ ), the percentage of increase in the ultimate load is $5.6 \%$ and $11.8 \%$ for $\mathrm{b}_{\mathrm{s}} / \mathrm{t}_{\mathrm{s}}=8.6$ and $\mathrm{b}_{\mathrm{s}} / \mathrm{t}_{\mathrm{s}}=7.5$ respectively. And for $\mathrm{h}_{\mathrm{w}} / \mathrm{t}_{\mathrm{w}}$ $=60\left(\right.$ web status $\left.A^{*}\right)$, the percentage of increase in the ultimate load is $7.7 \%$ and $14.1 \%$ for $b_{s} / t_{s}=8.6$ and $b_{s} / t_{s}=7.5$ respectively. A more ductile behavior can be obtained by increasing the concrete slab thickness as shown in figures 47 and 48 . The percentage of increase in the ductility resulted from increasing the concrete slab thickness to $14 \mathrm{~cm}$ and $16 \mathrm{~cm}$ is $14 \%$ and $29 \%$ in average, respectively, for beams with span to depth ratio $=15$. From Figure 48 , it can be seen that the beams with $h_{w} / t_{w}=60$ behave the least ductile one as its failure was no longer controlled by buckling, which is consistent with the results obtained before in the previous 
section. Regarding to the initial stiffness, an increase in its values can be achieved by increasing the concrete slab thickness as shown in Figures 49 and 50. For example, starting from $b_{s} / t_{s}=10$, for $h_{w} / t_{w}=86$ (web status $D^{*}$ ), the percentage of increase in the initial stiffness is $10.3 \%$ and $23.1 \%$ for $b_{s} / t_{s}=8.6$ and $b_{s} / t_{s}=7.5$ respectively. And for $h_{w} / t_{w}$ $=60$ (web status $A^{*}$ ), the percentage of increase in the initial stiffness is $10.3 \%$ and $20.5 \%$ for $b_{s} / t_{s}=8.6$ and $b_{s} / t_{s}=7.5$ respectively.

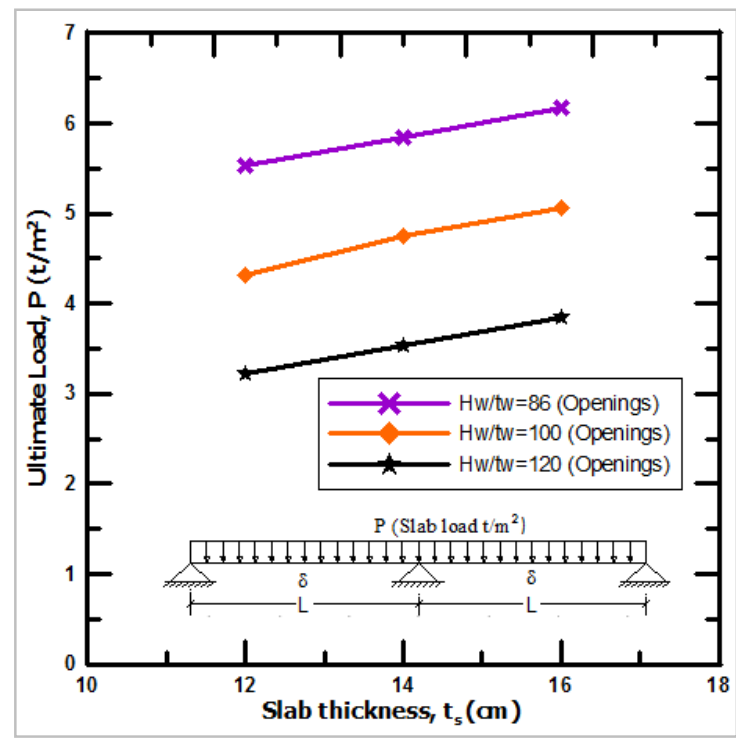

Fig 45: Effect of changes in concrete slab thickness on ultimate load

(Beams with $\mathrm{L} / \mathrm{h}_{\mathrm{w}}=15$ \& web status $\mathrm{D}^{*}$ )

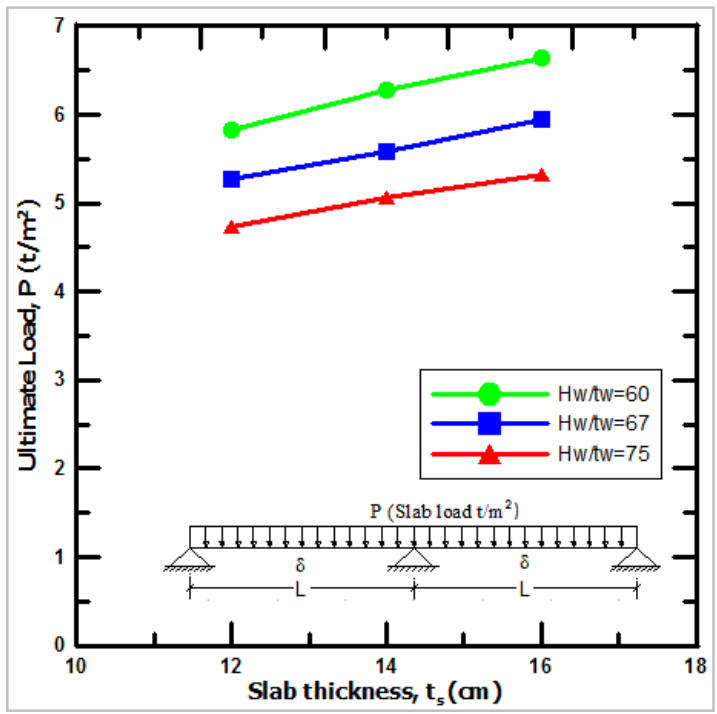

Fig 46: Effect of changes in concrete slab thickness on ultimate load (Beams with $L / h_{w}=15 \&$ web status $A^{*}$ )

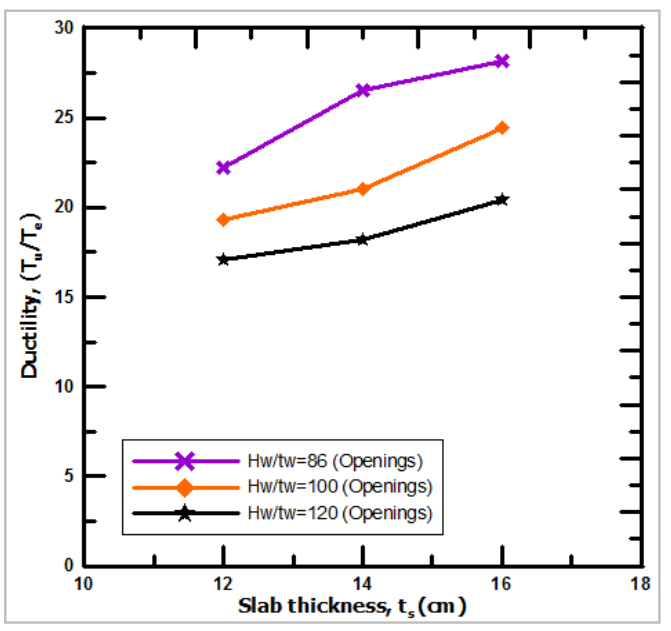

Fig 47: Effect of changes in concrete slab thickness on ductility

(Beams with $L / h_{w}=15 \&$ web status $D^{*}$ )

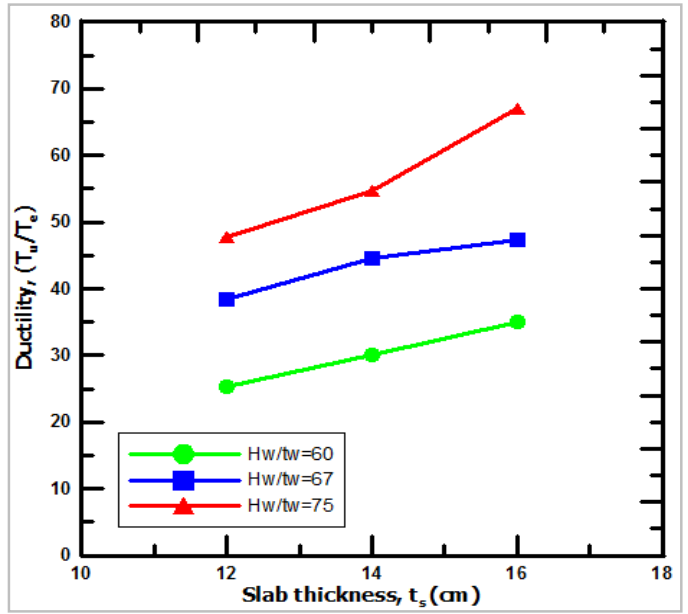

Figure 48: Effect of changes in concrete slab thickness on ductility (Beams with $L / h_{w}=15 \&$ web status $\left.A *\right)$

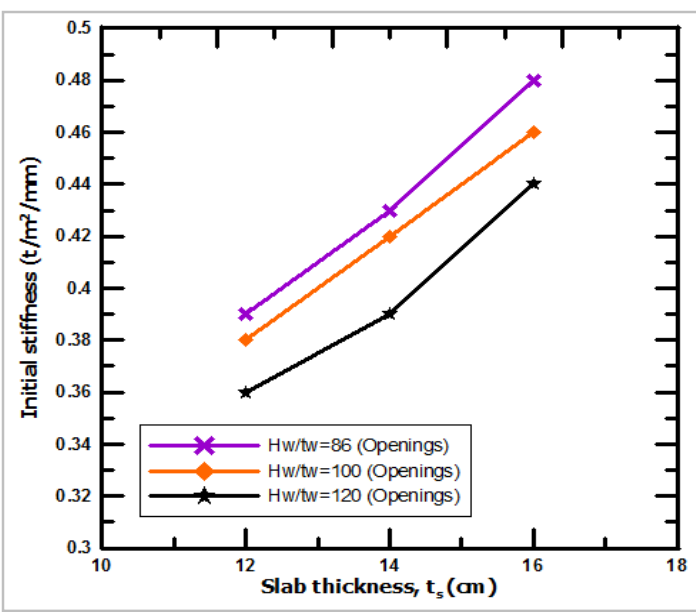

Fig 49: Effect of changes in concrete slab thickness on initial stiffness

(Beams with $L / h_{w}=15 \&$ web status $D^{*}$ ) 


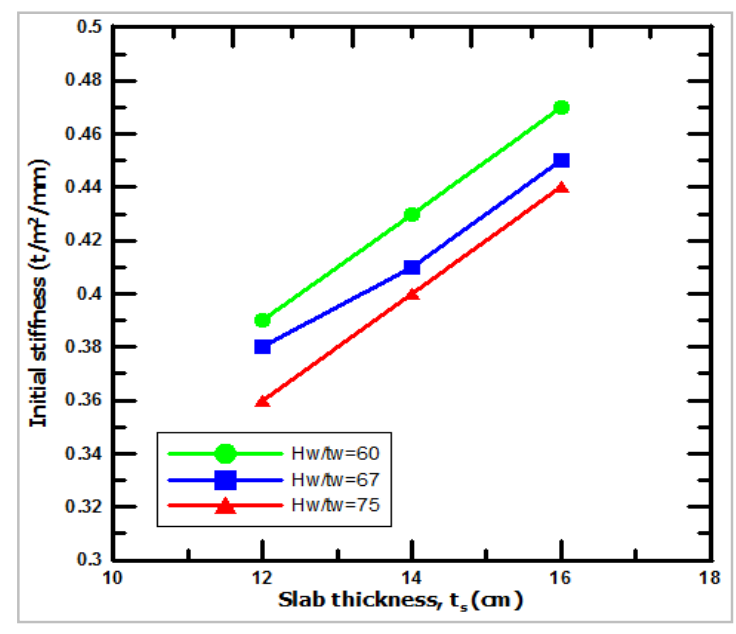

Fig 50: Effect of changes in concrete slab thickness on initial stiffness (Beams with $L / h_{w}=15 \&$ web status $A^{*}$ )

Comparisons are made between beams with different span to depth ratios and web statuses in regard to the effect of concrete slab thickness. It is found that there is a good improvement in the overall behavior resulted from increasing the concrete slab thickness appeared in the high percentages of increase in the ultimate load that is achieved for all beams, as an increase in the slab thickness would raise the neutral axis of the composite beams, hence increasing the lever arm of the section.

\section{CONCLUSIONS AND RECOMMENDATIONS}

\subsection{Conclusions}

1. An efficient nonlinear 3D finite element model has been developed using ABAQUS software taking into consideration the initial geometric imperfection and material nonlinearities, and the results were compared with published experimental data, where a good agreement was found in both elastic and plastic ranges.

2. Increasing the web thickness leads in general to an increase in the ultimate load, the initial stiffness, and the ductility for the beams that its failure is governed by buckling, so it can be an effective tool for enhancing the behavior of the beams.

3. It can be concluded that the beams with web slenderness more than (70-80), its failure is controlled by steel web buckling. While those with web slenderness less than (70-80), the concrete controls the failure which in turns decreases the ductility.

4. Using vertical stiffeners resulted in an increase in the ultimate load and the initial stiffness by $12 \%$ \& $2 \%$, respectively, as vertical stiffeners give a small increase in the initial stiffness over the normal castellated beam.

5. Using stiffeners around the openings results in an increase in the ultimate load and the initial stiffness by $17 \% \& 10.5 \%$, respectively.

6. Starting the web openings after the negative moment region results in an increase in the ultimate load and the initial stiffness by $25 \%$ \& $18 \%$, respectively.

7. Compared to the normal castellated beam, the ductility ratio decreases by $50 \%, 61.2 \%$ and $68.6 \%$ for vertical stiffeners, stiffeners around openings and starting the web openings after the negative moment region, respectively.

8. The percentages of increase in the ultimate loads that can be gained from using vertical stiffeners, stiffeners around openings \& starting the openings after negative bending moment region were higher for beams with span to depth ratio $=15\left(\mathrm{~L} / \mathrm{h}_{\mathrm{w}}=15\right)$ and having high web slenderness. This means that when there is high probability that the buckling of the web controls the failure (in case of high web slenderness and high span to depth ratio), these solutions are more effective.

9. For high web slenderness $\left(h_{w} / t_{w}=120\right)$ improving the buckling capacity by decreasing the web slenderness from 120 to 100 is more effective than using solutions $\mathrm{B}^{*}, \mathrm{C}^{*} \& \mathrm{D}^{*}$. However, for $h_{w} / t_{w}=100$, using solution $D^{*}$ is more effective than decreasing the web slenderness from 100 to 86 . While for $h_{w} / t_{w}=86$, using solutions $C^{*} \& D^{*}$ is more effective than decreasing the web slenderness from 86 to 75 .

10. The variation of the steel strength is very effective in improving the behavior of the composite castellated beams in the plastic stage, while there is no change in the initial stiffness which depends on the constant modulus of elasticity.

11. Increasing the steel strength to $f_{y}=275 \& f_{u}=430$ $\mathrm{MPa}$ and to $\mathrm{f}_{\mathrm{y}}=355 \& \mathrm{f}_{\mathrm{u}}=510 \mathrm{MPa}$ results in an increase in the ultimate load by $6.5 \%$ \& $18.5 \%$ respectively, and a decrease in the ductility by $18.5 \%$ \& $31 \%$ respectively.

12. The effect of concrete strength on the behavior of the castellated composite beams was studied through the use of different concrete compressive strengths in the slab and in the associated push-out tests represented by the load-slip curves of shear connectors.

13. The variation of concrete strength has almost no influence on the initial stiffness, while we can achieve a $4 \%$ increase in the strength and a $23 \%$ increase in the ductility by increasing the concrete strength from 34 to $40 \mathrm{MPa}$.

14. Decreasing the slab slenderness causes an increase in the ultimate load by $7 \%$ \& $14 \%$ for $\mathrm{b}_{\mathrm{s}} / \mathrm{t}_{\mathrm{s}}=8.6 \&$ $\mathrm{b}_{\mathrm{s}} / \mathrm{t}_{\mathrm{s}}=7.5$, as an increase in the slab thickness would raise the neutral axis of the composite beams, hence increasing the lever arm of the section, also the ductility increases by $18.5 \%$ \& $34 \%$ and initial stiffness increases by $6.5 \% \& 15 \%$ by increasing the slab thickness.

\subsection{Recommendations}

1. The shear connectors were carefully modeled using several methods to find the most efficient method and it can be recommended that for modeling of full shear connection, using the General multi-points 
constraints (MPC constraints) gives the best solution, while for modeling of partial shear connection, using the Nonlinear elastic connector elements and Contact interactions gives the best solution.

2. It is recommended that for high web slenderness to increase the web thickness other than using the other solutions and vice versa for low web slenderness to enhance the behavior of the beams.

3. After comparing the results of the changes that were done to the web, it can be recommended to start the web openings after the negative moment region to obtain the highest ultimate load and initial stiffness, and for the ductility, using vertical stiffeners is the best solution.

4. It is recommended to increase the concrete slab thickness other than increasing the concrete strength to enhance the behavior of the beams.

\section{Future works}

It is proposed to study the behavior of continuous steel concrete composite castellated beams under cyclic/dynamic loads.

\section{REFERENCES}

[1] Nethercot, D. A, Kerdal, D., (1982). Lateral torsional buckling of castellated beams. The Structural Engineer, 60B (3), 53-61.

[2] Larnach, J.W., and Park, R. (1964). The behavior under load of six castellated composite T-beams. Civ. Engng. and Pub, Works, 59:692, 339-343.

[3] Giriyappa, J. and Baldwin, J.W. (1966). Behavior of composite castellated hybrid beams. Univ. of Missouri Engng. Experimental Res. Station, Columbia. Mo., USA.

[4] Hartono. W., and Chiew. S.P. (1996). Composite behavior of half castellated beam with concrete top slab. Advances in Steel Structures. Proceedings of a conference in Hong Kong. Pergamon. Editors: S.L. Chan and J.G. Teng.pp 437-442.

[5] Megharief, J. D., (1997). Behavior of composite castellated beams. MSc thesis, McGill University, Montreal.

[6] Gizejowski, M. A., Salah, W., (2011). Numerical modeling of composite castellated beams. Proc. Local Seminar of the polish Chapter of IASS, Warsaw, 554565 .

[7] Salah, W., Gizejowski, M. A., (2008a). Numerical finite element modeling of the stability behavior of slender section steel-concrete composite beams with web openings. Proc. Local Seminar of the polish Chapter of IASS, Warsaw, 76-86.

[8] Salah, W., Gizejowski, M. A., (2008b). Experimental investigation of the stability behavior of slender section steel-concrete composite beams with web openings.
Proc.Local Seminar of the polish Chapter of IASSWarsaw, 68-75.

[9] Gizejowski, M. A., Salah, W. (2007). Failure modes of composite beams in the hogging moment region of continuous or semi-continuous systems. Proc. Local Seminar of the Polish Chapter of IASS, Warsaw, 114 136.

[10] Gattesco, N., (1999). Analytical modelling of nonlinear behavior of composite beams with deformable connection. Journal of Constructional Steel Research, 52, 195-218.

[11] Carreira, D.J., and Chu, K.H., (1985). Stress-Strain relationship for plain concrete in compression. ACI Struct.J., 82(11), 797-804.

[12] Eurocode 4 (1992), ENV 1994-1-1:1992 - Design of composite steel and concrete structures Part: 1-1: General rules and rules for buildings. Brussels

[13] Baskar, K.; Shanmugam, N. E.; Thevendran, V. (2002). Finite element analysis of steel-concrete composite plate girder, Journal of Structural Engineering 128(9): 11581168 .

[14] Liang, Q., Uy, B., Bradford, M. and Ronagh, H., (2005). Strength analysis of steel-concrete composite beams in combined bending and shear, Journal of Structural Engineering. ASCE, 131(10), 1593-1600.

[15] Hibbitt, Karlsson and Sorensen, (2008). ABAQUS standard user's manual. Inc. vols. 1, 2 and 3. Version 6.8-1. USA.

[16] Chapman, J.C. and Balakrishnan, S., (1964) Experiments on composite beams. The Structural Engineer 42(11), 369-383.

[17] Ansourian P., (1981). Experiments on continuous composite beams. Proc. Inst. Civil Eng., Part 2, 25-51.

[18] El-Lobody, E., Lam, D., (2003). Finite element analysis of steel-concrete composite girders. Advances in Structural Engineering, 6(4), 267-81.

[19] Dabaon, M. A., (2002). Effective width of composite beam at region of negative moment. Scientific Bulletin, Ain Shams University, Faculty of Engineering, 37(1), 85-109.

[20] Donahey, R. C. and Darwin, D., (1986). Performance and design of composite beams with web opening. SM Report No. 18, University of Kansas Center for Research, Lawrence, Kansas, USA (April).

[21] Eurocode 3, (2007). Design of steel structures part 1-12: additional rules for the extension of EN 1993 up to steel grades S 700. London (UK): British Standards, Institution, BS EN 1993-1-12.

[22] Mashaly, E. M., Zien Eldin, H., El-Heweity, M., Ismail, R. and Ismail, H., (2010). Behavior of stub girder floor system with partial shear connection. Alexandria Engineering Journal 49,357-370. 